\title{
PALAEOENVIRONMENTAL RECONSTRUCTIONS FOR THE NEOLITHIC PILE-DWELLING SERTEYA II SITE CASE STUDY, WESTERN RUSSIA
}

\author{
Warunki paleogeograficzne rozwoju neolitycznej \\ osady palafitowej Serteya II (zachodnia Rosja)
}

\author{
PIOTR KITTEL ${ }^{*}$, ANDREY MAZURKEVICH $^{\star *}$, EKATERINA DOLBUNOVA ${ }^{\star *}$, \\ EDUARD KAZAKOV ${ }^{\star \star \star}$, AGNIESZKA MROCZKOWSKA $^{*}$, ELENA PAVLOVSKAIA ${ }^{\star \star \star *}$, \\ WIKTOR PIECH ${ }^{\star}$, MATEUSZ PŁÓCIENNIK $^{\star \star \star \star \star}$, JERZY SIKORA ${ }^{\star \star \star \star \star \star \star}$, \\ YULIA TELTEVSKAYA ${ }^{\star \star \star \star \star \star \star}$, MAGDA WIECKOWSKA-LÜTH ${ }^{\star \star \star \star \star \star \star \star ~}$
}

\begin{abstract}
The article presents the results of recent archaeological and geomorphological research conducted on Middle to Late Neolithic site Serteya II in the Serteysky microregion of the Dnepr-Dvina region (NW Russia). The interaction of archaeological and multidisciplinary palaeoenvironmental research allowed for the reconstruction of the natural environment transformations and the natural conditions of the activity of the ancient communities in the lower Serteyka River valley, the left-bank tributary of the Western Dvina River. The terrain relief of the area was formed after the recession of the Weichselian (Valdai) Ice Sheet. The present day Serteyka River valley occupies a subglacial channel that was earlier occupied by a few lake basins of almost two generations. The water basins of the first generation existed within glacial crevasses and between blocks of dead ice, and second generation lakes developed after the melting of dead ice in the Late Valdai. Throughout the entire Holocene, the Serteyka River drained several lake basins as a result of headward river erosion. The Neolithic Serteya II site occupied the surface of a kame terrace and biogenic plain within the palaeolake basin. The pile-dwelling settlement functioned there in a period when palaeolakes existed and were affected by transgression and regression of the water table. The main phase of pile-dwelling development is dated to ca. 4200-3800 cal BP and existed for almost 140 years. It was part of a wider settlement structure in the period of domination of a hunter-gatherer economy and the beginning of agriculture.
\end{abstract}

Key words: recently glaciated area, palaeolake systems, river valley, pile-dwelling settlement, Neolithic

Zarys treści. Artykuł przedstawia wyniki ostatnich badań archeologicznych i geomorfologicznych środkowo- i późnoneolitycznego stanowisku Serteya II, zlokalizowanego w międzyrzeczu Dniepru i Dźwiny, w obrębie mikroregionu Sertejskiego (NW Rosja). Połączenie wyników badań archeologicznych i multidyscyplinarnych analiz paleośrodowiskowych pozwoliło na odtworzenie środowiska naturalnego i warunków przyrodniczych działalności dawnych społeczności w dolinie dolnej Sertejki, lewego dopływu Dźwiny. Rzeźba terenu została uformowana po ustąpieniu zlodowacenia wisły (wałdajskiego). Współczesna dolina wykorzystuje rynnę subglacjalną, w której wcześniej funkcjonowało kilka basenów jeziornych dwóch generacji. Zbiorniki pierwszej generacji rozwinęły się w szczelinach lodowych i w obniżeniach pomiędzy martwymi bryłami lądolodu. Jeziora drugiej generacji powstały po wytopieniu brył martwego lodu w późnym vistulianie. W trakcie holocenu rzeka Sertejka, w wyniku erozji wstecznej, zdrenowała kolejne jeziora. Osada neolityczna Serteya II zajmowała powierzchnię

* University of Lodz, Faculty of Geographical Sciences, Department of Geomorphology and Palaeogeography, ul. Narutowicza 88, 90-139 Łódź, Poland; e-mail: piotr.kittel@geo.uni.lodz.pl, A_Mroczkowska@outlook.com, piechwiktor@gmail.com

** The State Hermitage Museum, Dvortsovaya Naberezhnaya 34, 190000 Saint Petersburg, Russia; e-mail: a-mazurkevich@mail.ru,katjer@mail.ru

*** Nansen International Environmental and Remote Sensing Center, 14th Line 7 V.O., 199304 Saint Petersburg, Russia; e-mail: ekazakov@niersc.spb.ru

**** Saint Petersburg State University, Institute of Earth Sciences, Department of Geophysics, 7 Universitetskaya Embankment, 199034 Saint Petersburg, Russia; e-mail:pavlovskaia.elena@gmail.com

***** University of Lodz, Faculty of Biology and Environmental Protection, Department of Invertebrate Zoology and Hydrobiology, ul. Banacha 12/16, 90-237 Łódź, Poland; e-mail: mplociennik10@outlook.com

****** University of Lodz, Institute of Archaeology, Department of Historical Archaeology and Weapon Studies,

ul. G. Narutowicza 65, 90-131 Łódź, Poland; e-mail: jerzy.sikora@uni.lodz.pl

******* Saint Petersburg State University, Saint Petersburg, Russia; e-mail: yulya.teltevskaya@mail.ru

******** Christian-Albrechts-University, Institute of Prehistoric and Protohistoric Archaeology, Archaeobotanical and Palynological Laboratory, Kiel, Johanna-Mestorf-Straße 2-6, 24118 Kiel, Germany; e-mail: mwickowska@ufg.uni-kiel.de 
terasy kemowej oraz wkraczała na równinę biogeniczną w obrębie basenu jeziornego. Osadnictwo palafitowe funkcjonowało podczas okresów transgresji i regresji paleojezior. Główny okres jej rozwoju przypadał na 4200-3800 cal BP i trwał ponad 140 lat. Osada stanowiła część większej struktury osadniczej rozwijającej się w okresie przechodzenia lokalnych społeczności od gospodarki łowiecko-zbierackiej do prymitywnego rolnictwa.

Słowa kluczowe: obszar młodoglacjalny, systemy paleojeziorne, dolina rzeczna, osadnictwo palafitowe, neolit

\section{Introduction}

The Serteya region is situated in Western Russia on the border between three regions - the Pskov, Smolensk and Tver oblasts. The region lies within the recently glaciated Vitebsk Lakeland (according to Kondracki 1992) or the Western Dvina Lakeland (according to Abramov 1972). It is situated near to the Central Russian Upland and close to the European watershed of three catchments: the Baltic Sea, the Black Sea and the Caspian Sea. The main watercourse of the area is the Western Dvina, but the main axis of the studied region is the Serteyka River, an approximately $40-\mathrm{km}$-long left tributary of the Western Dvina River. The main traits of the terrain of this recently glaciated area were formed during the Valdai (Weichselian) Glaciation (Figs 1,2 ) and, with its rich natural resources, the land- scape offered favourable conditions for ancient settlers.

The area is located within a temperate zone of broadleaf deciduous forest. The studied region occupies a particular place in research on the Neolithisation processes of Eastern Europe, hosting sites of the earliest ceramic ware connected with the primary ceramic centres of southern Eastern Europe (Mazurkevich, Dolbunova 2015; Kul'kova et al. 2015a). It also supplies valuable evidence regarding the adaptation of Middle and Late Neolithic communities to the changing environmental conditions of the transition between the Atlantic and Subboreal Periods (Mazurkevich et al. 2009a, 2011, 2017a, b; Kul'kova et al. 2015b), where the construction of pile-dwellings might have been one of the forms of such an adaptation, which marks a cultural discontinuity and major environmental changes.

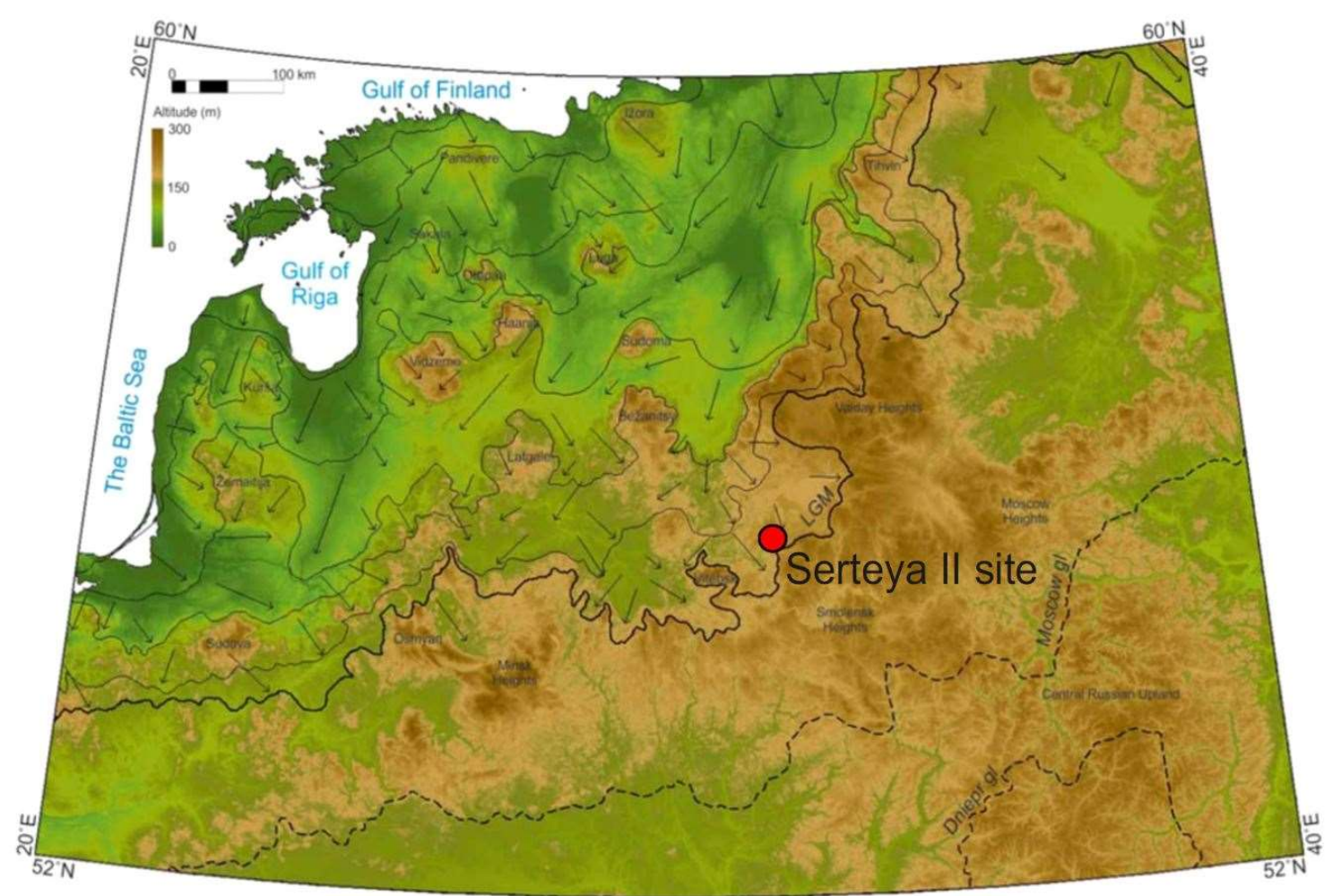

Fig. 1. Research area against the limit of the LGM, after Gorlach et al. (2015)

Obszar badań na tle zasięgu LGM wg Gorlacha i in. (2015) 


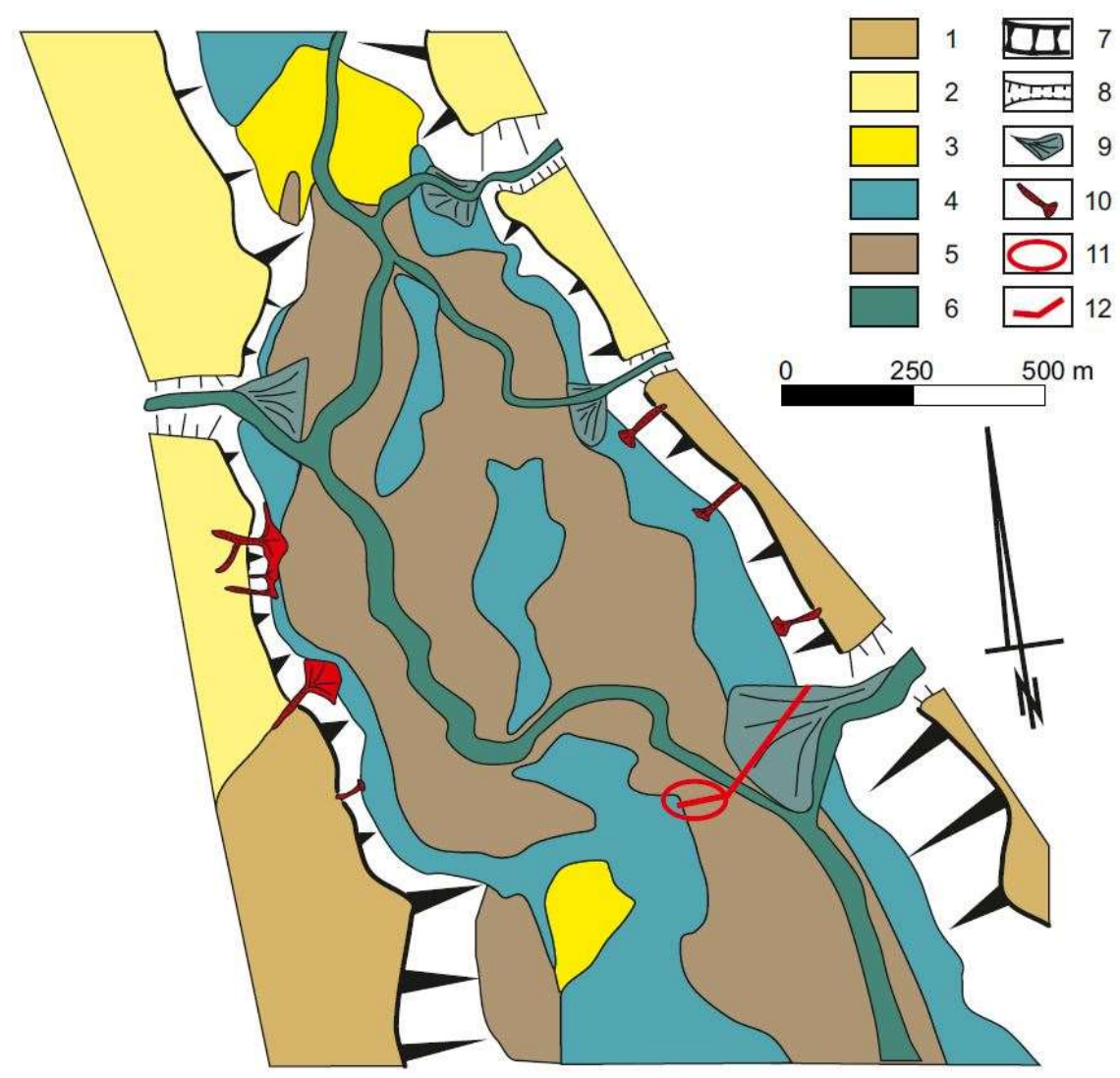

Fig. 2. Geomorphological sketch of the Serteya II site area

1 - moraine plateau, 2 - glaciofluvial plain, 3 - crevasse fills, 4 - kames and kame terraces, 5 - biogenic plains, 6 - flood plain, 7 - subglacial channel, 8 - valley slopes, 9 - alluvial fans, 10 - gullies, erosional cuts and proluvial-deluvial fans, 11 site area, 12 - geological cross-section line (see Fig. 8)

\section{Szkic geomorfologiczny otoczenia stanowiska Seteya II}

1 - wysoczyzny morenowe, 2 - równiny wodnolodowcowe, 3 - formy szczelinowe, 4 - kemy i terasy kemowe, 5 - równiny akumulacji biogenicznej, 6 - równiny zalewowe, 7 - rynna subglacjalna, 8 - zbocza dolin, 13 - stożki napływowe, 10 wąwozy, parowy, rozcięcia erozyjne i stożki proluwialno-deluwialne, 11 - obszar stanowiska, 12 - linia przekroju geologicznego (vide rys. 8)

Several pile-dwelling sites are known in the eastern Baltic region. They existed at about the same time as they did in the foothills of the Alps in Western Europe (Dolukhanov, Mazurkevich 2000). The first pile-dwellings existed in the Western Dvina-Lovat' region from ca. 5700 BP. The wooden constructions were based on poles and situated in the shore and/or littoral zones of lakes. Cultural layers of these sites are often discovered within lacustrine deposits as a result of later lakes' transgression, and therefore found artefacts and ecofacts are in a unique state of preservation. The appearance of pile-dwellings was probably a specific form of adaptation to the particular landscape and climatic conditions. The second stage of the existence of pile-dwelling settlement functioned near to (or even during) the 4200 years BP cooling event (see: Dolukhanov, Miklyayev 1986; Mazurkievich, Dulbanova 2011; Mazurkevich et al. 2011, 2014; Kul'kova et al. 2015b).
The Serteya II site revealed remains of several settlements with a core zone occupied by several pile-dwelling constructions dated to the period from ca. 4900 to ca. $3800 \mathrm{cal} \mathrm{BP}$. It is situated in the present day Serteyka River Valley, close to Rudnya village. The site lies on the southern border of the Great Serteya Palaeolake Basin (GSPB).

Detailed mapping of the area with the use of geological augering and outcrops, supplemented by analyses of topographical maps and aerial photographs, combined with geophysical prospections documented thick organic sediments and alluvial deposits within post-lake basins. Detailed palaeoecological reconstructions were important to the understanding of natural landscape evolution and human-environment relationships on the Eastern European Plain. The multidisciplinary palaeoenvironmental research, which was based on an extensive geological and geomorphologic survey and preliminary palaeoecological research, allowed for 
the reconstruction of both the settlement location conditions and the natural environment transformations and the natural conditions for the activity of the ancient communities in the former lake basin area.

\section{Study methods}

The site was found in 1971, and investigations were renewed in 2008. Different parts of the Serteya II site situated both on the surface of mineral sediments and within lacustrine deposits were studied. Within the organic deposits, pile-dwelling constructions were excavated with using underwater and wetland archaeological methods. During the archaeological excavations of the site, all find locations were 3D-recorded along with detailed observation of the microstratigraphy of cultural and lithological sediments. Typological analysis of artefacts and further 3D analysis of their distribution is regarded to be an important proxy for interpretation of the formation and chronology of cultural layers.

A detailed geological survey was carried in order to recognise the surficial geology of the Serteya II archaeological site surroundings. This was based on hand augering with the use of Eijkelkamp equipment with different kind of endings (e.g.: Edelman, gouge auger, peat sampler). In total, ca. 100 cores have been made at depths of 1.2 to 8.5 metres. Some of the drillings were situated in the cross-section line of the GSPB in the Serteya II surroundings (Fig. 2). A few boreholes were made outside the cross-section lines, too. The geological work was also investigated with the use of archaeological trenches and geological outcrops. The archaeological trenches allowed the detailed study of subsurface deposits.

Ground-penetrating radar (GPR) was used for the detection of archaeological features and structures, as well as geological deposits. This is a noninvasive geophysical technique that detects electrical discontinuities in the shallow subsurface. It is based on the generation, transmission, propagation, reflection and reception of discrete pulses of high frequency $(\mathrm{MHz})$ electromagnetic energy. The GPR survey on the Serteya II archaeological site area was conducted in August 2017 using the "OKO-2" georadar using an antenna with a centre frequency of $150 \mathrm{MHz}$ (LOGIS-GEOTECH Company). The aims of the GPR survey were (1) rectification of the geological section based on the drilling data, (2) to locate and determine the thickness of the lake sediments, and (3) to search for river palaeochannels. The location of GPR profiles was referenced to drilling points (Fig. 3). The data were processed using GeoScan32 software.

Topographic and geodetic observation provided detailed spatial configurations of modern relief, water bodies, swamps, vegetation, etc. Highquality spatial data opens up profound possibilities for the interpretation of geological and archaeological information.

A basic topographic survey at Serteya was made in 1995-1996 using plan table survey and theodolites at 1:5,000 scale (Fig. 4), which was later digitised and integrated into a GIS. In 2014 a new network of geodetic points was created, which covered the main survey sites and included 10 geodetic points, the coordinates of which were determined by static GNSS observations based on the point of the Russian state geodetic network with an absolute accuracy of about 2-3 centimetres. The geodetic network on the overview map is shown in Fig. 5.

High-scale topographic surveys (from 1:1,000 to $1: 100$ ) using total stations and post-processing kinematic (PPK) method with geodetic satellite receivers were produced on the basis of this network. Also, experimental work was carried out to survey the relief of one of the key areas with ultrahigh detail (with a surveying step of about 40 centimetres), which allowed for a detailed surface reconstruction (Fig. 6) that was further correlated with the results of geophysical observations.

In 2016, aerial photography from a UAV was performed at Serteya with a low-cost DJI Phantom 3 Advanced drone based on the established network of ground control points. The network consisted of brightly-coloured plastic plates fixed on the terrain, with their coordinates determined with high accuracy by traverse and static GNSS observation methods. To automate aerial photography in the field, the DroneDeploy software was used, and photogrammetric software products Agisoft Photoscan and OpenDroneMap to process the data. As a result, orthophotomaps of the area with a resolution of 6 centimetres per pixel were obtained, as well as digital terrain models of the area with a resolution of about 25 centimetres per pixel (Fig. 7) (Kazakov 2016). Such materials are widely used in the interpretation of objects on the ground, the search for special areas, planning work, as well as auxiliary information in the conduct of research.

The results of geological mapping and observations within geological outcrops combined with geophysical prospections and a detailed topographic survey also supported the elaboration of the geological cross-section of the GSPB fill (Fig. 8). 

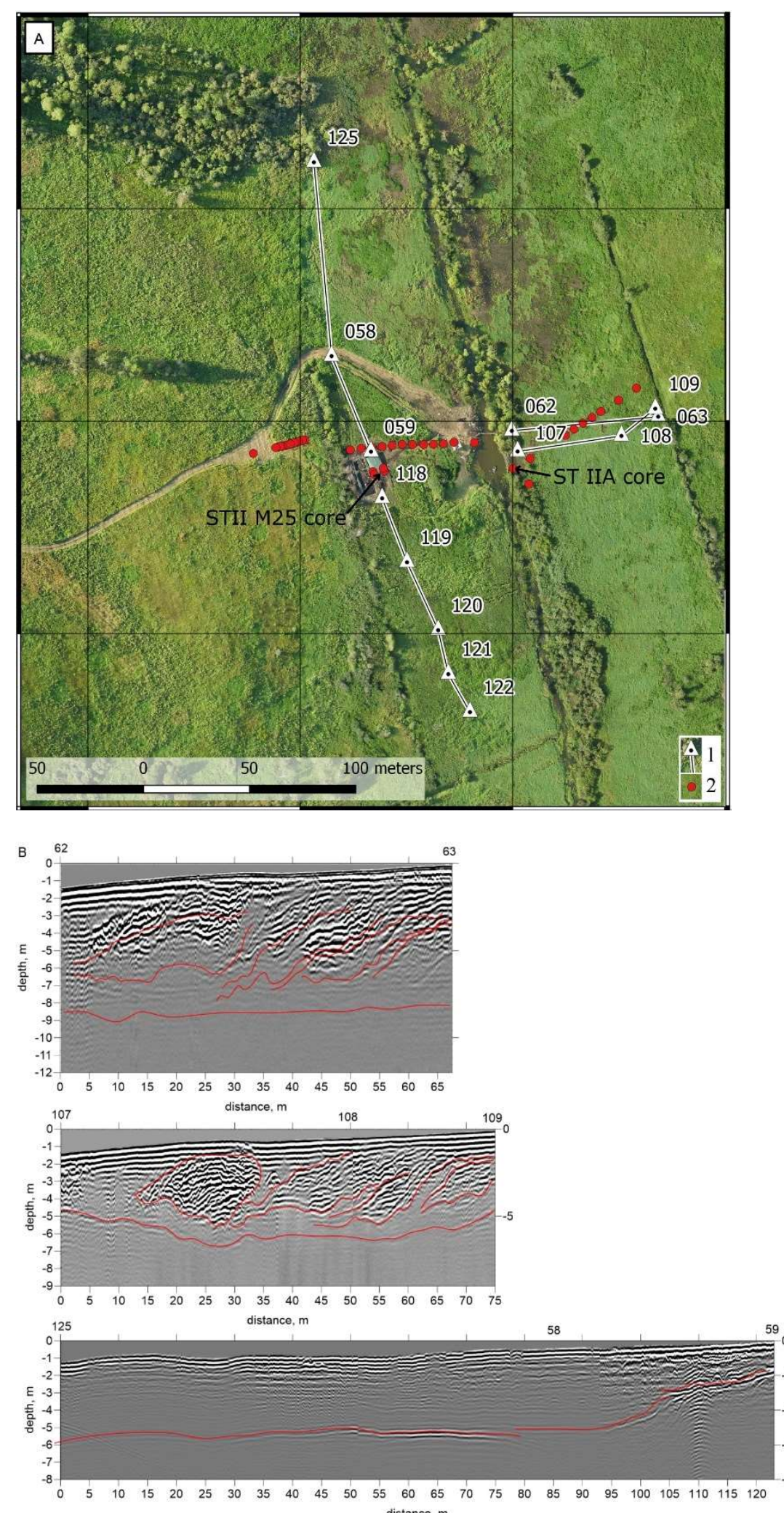

118

119 120

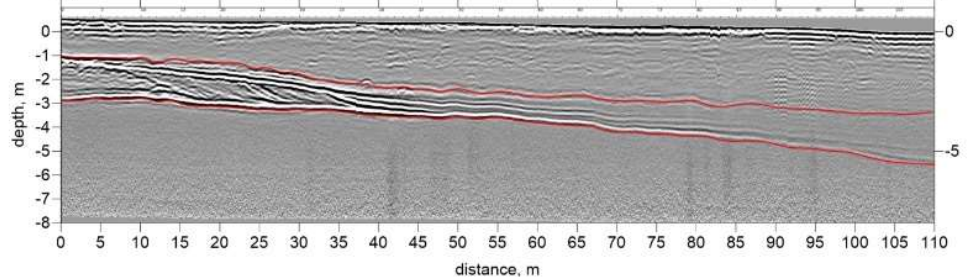

Fig. 3. Results of ground penetrating radar (GPR) survey

A - Location of ground penetrating 9. radar profiles on the Serteya II archaeological site

21 - profile lines, 2 - location of geological drillings

B - GPR sections

distance and depth in metres

Wyniki badań georadarowych (GPR)

A - Lokalizacja profili georadarowych na stanowisku Serteya II 1 - linie profili, 2 - położenie sondowań geologicznych B - przekroje GPR odległości i głębokości w metrach 


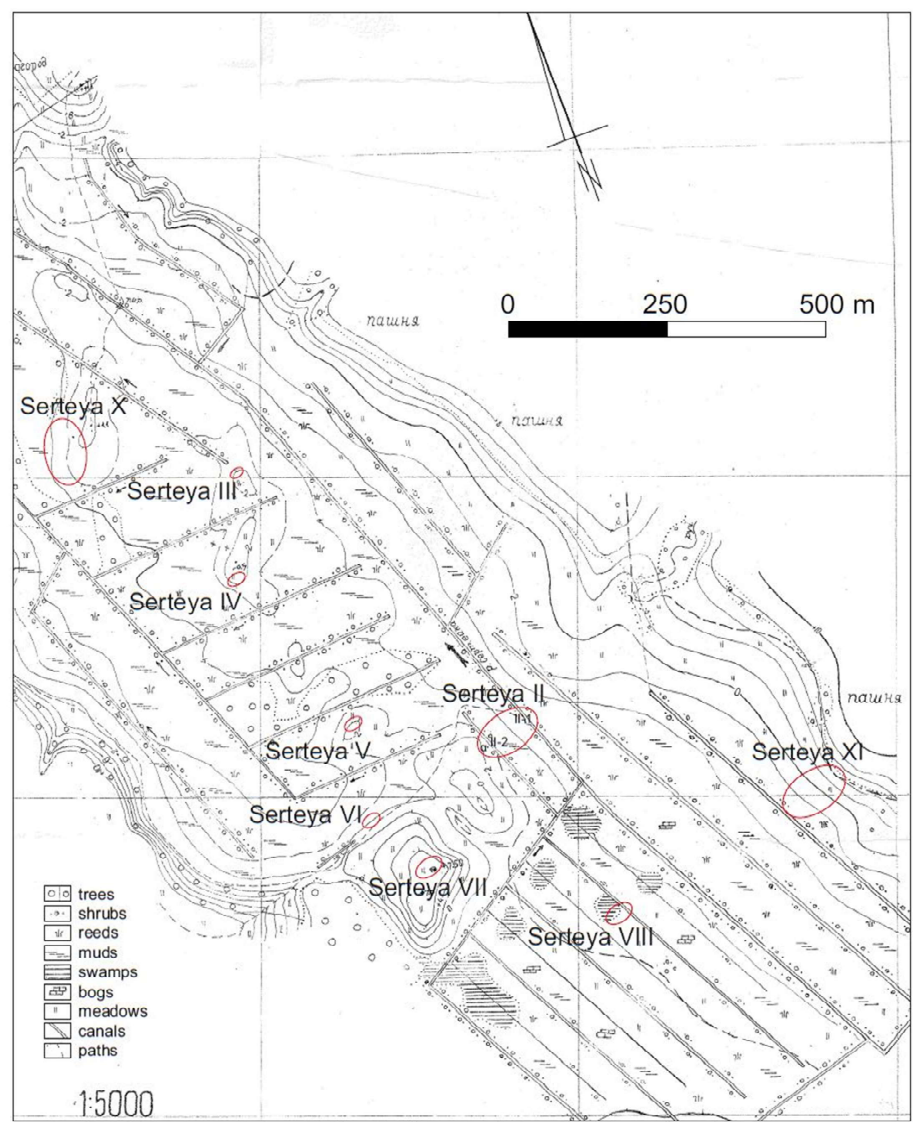

Fig. 4. Fragment of topographical survey performed in 1995-1996

Fragment planu topograficznego wykonanego w latach 1995-1996

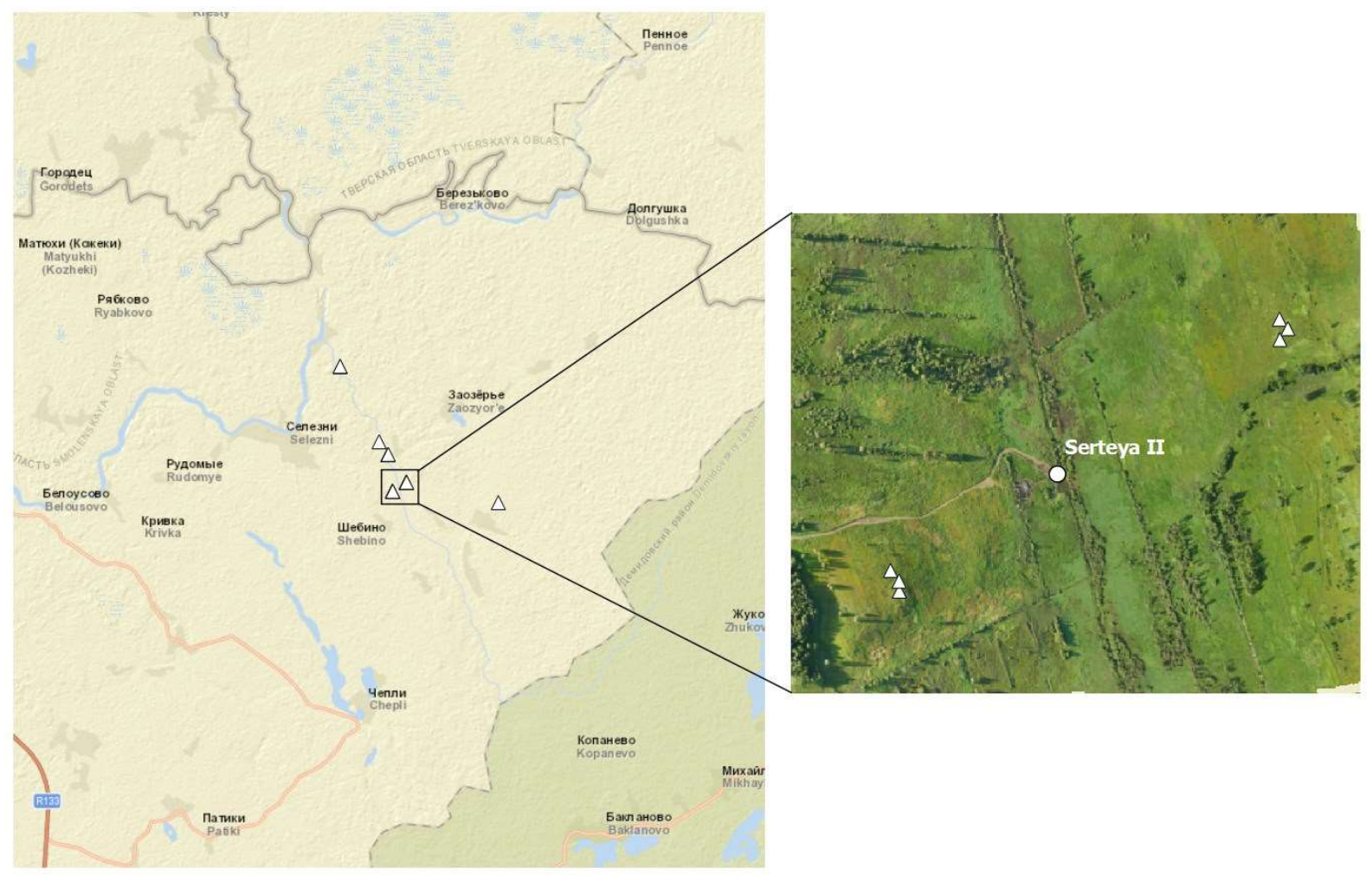

Fig. 5. Plan of local geodetic points developed for Serteya research geodetic points shown as triangles

Plan lokalnych punktów osnowy geodezyjnej opracowany dla badań w Serteji punkty geodezyjne są przedstawione jako trójkąty 


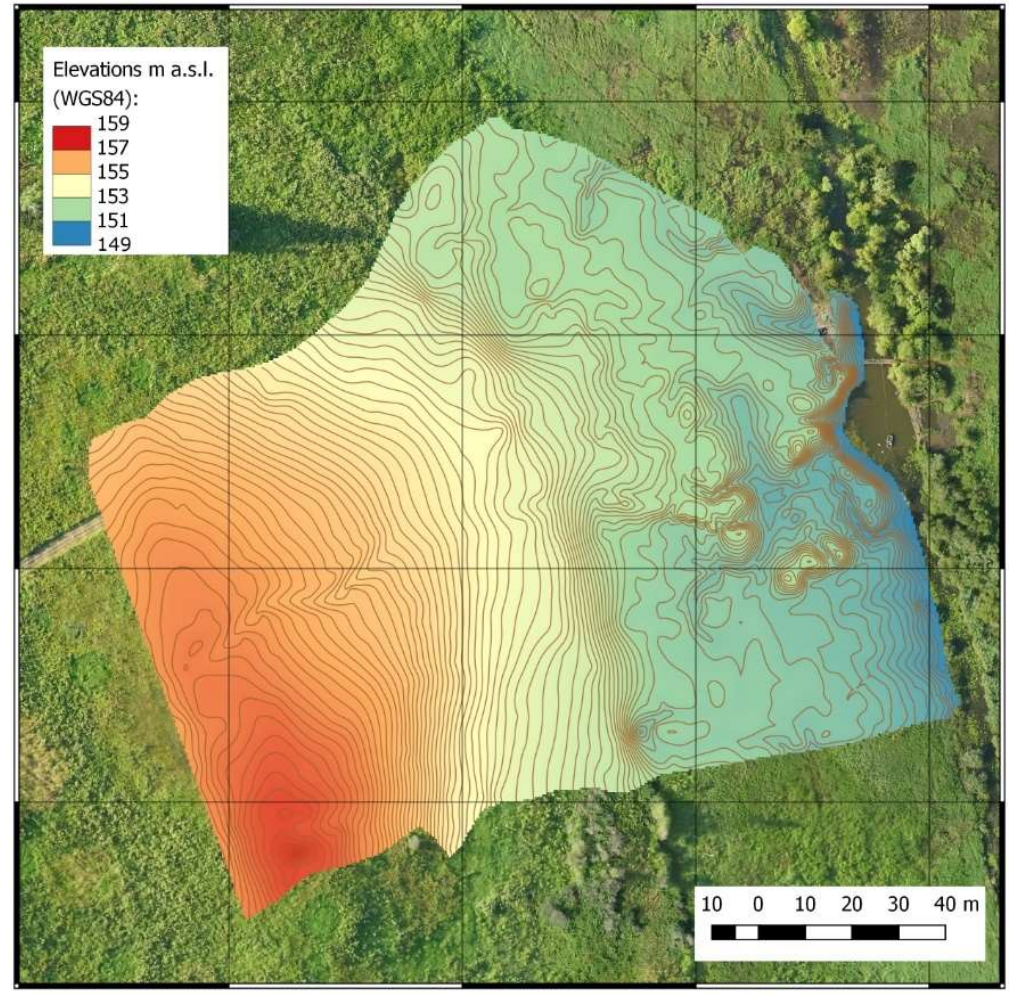

Fig. 6. High-detail relief survey at Serteya II site contours made for every 10 centimetres of elevation

Model terenu o wysokiej rozdzielczości dla stanowiska Serteya II poziomice poprowadzono co $10 \mathrm{~cm}$
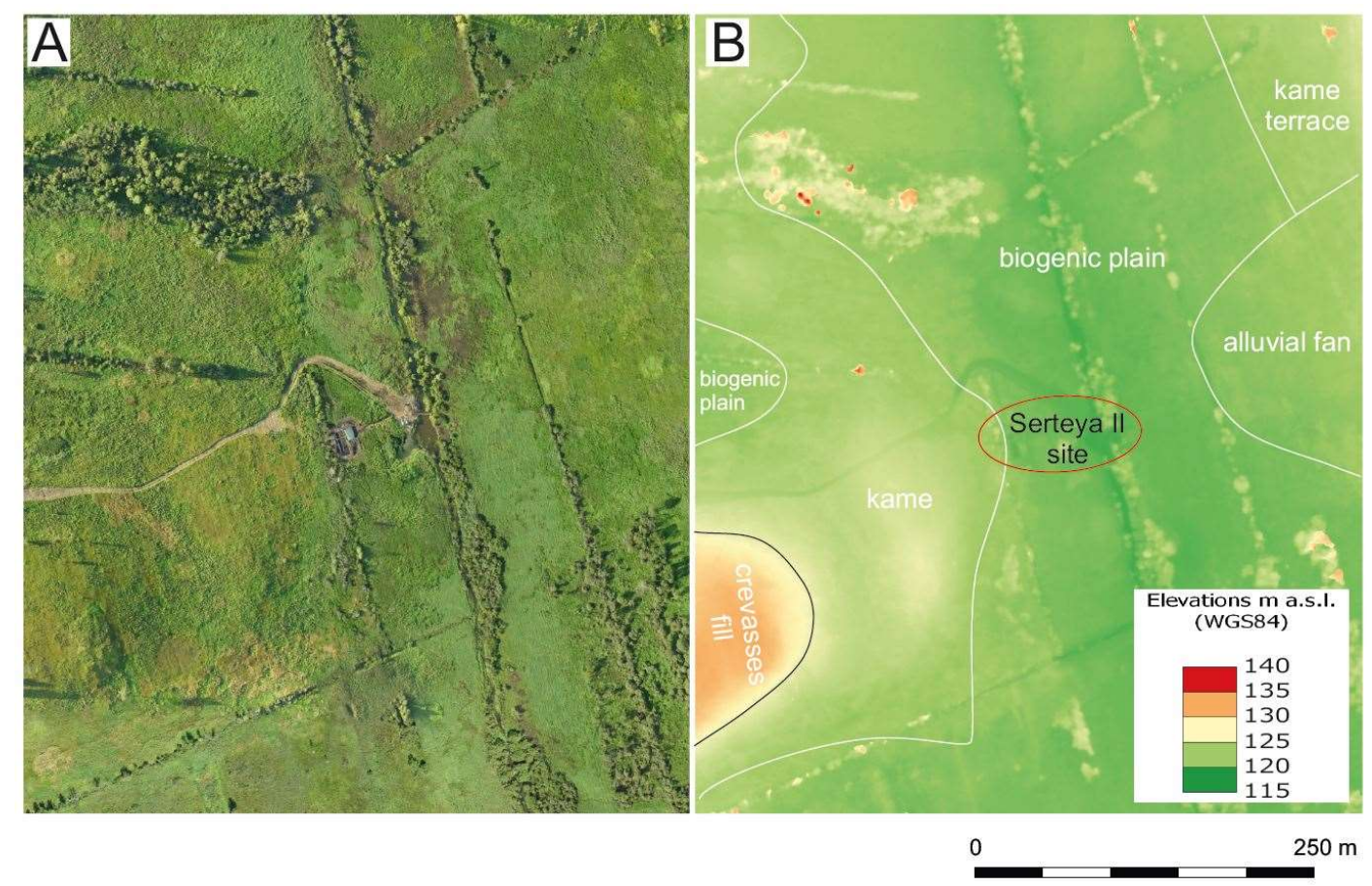

Fig. 7. Results of aerial photo surveying at Serteya II site A - Orthophotomap (resolution $6 \mathrm{~cm} /$ pixel), B - Digital terrain model (resolution $25 \mathrm{~cm} /$ pixel)

Wyniki prospekcji lotniczej dla stanowiska Serteya II A - Ortofotomapa (rozdzielczość $6 \mathrm{~cm} /$ pixel), B - Numeryczny model terenu (rozdzielczość $25 \mathrm{~cm} /$ pixel) 


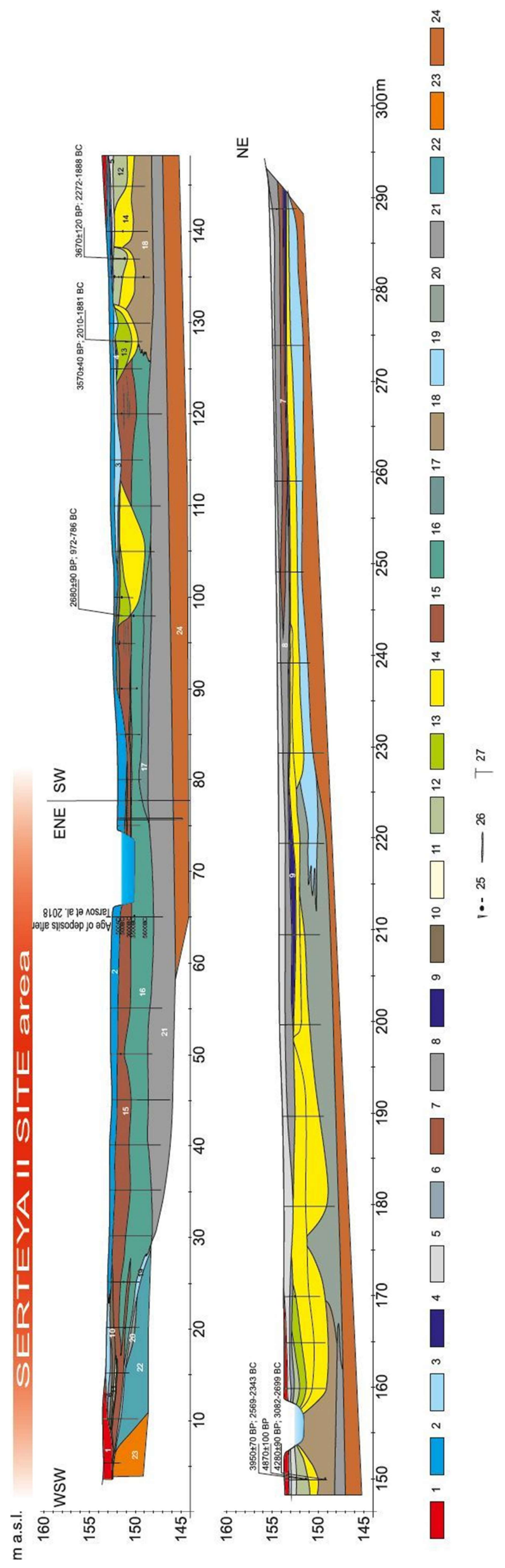

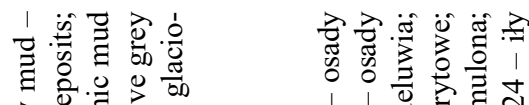

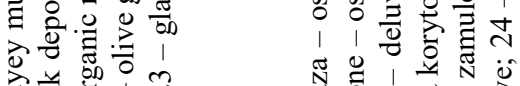
खे

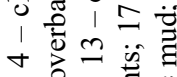

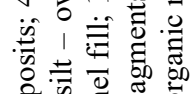
蛋

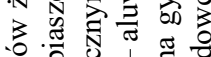
음

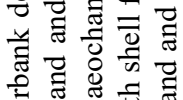
क क $\frac{\pi}{\pi}$ $\begin{array}{llll}3 & 1 & 0 & 3 \\ 1 & \infty & 1 & 0 \\ 0 & 0 & 0\end{array}$

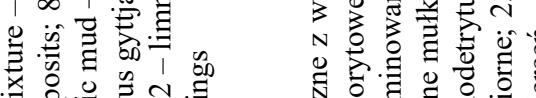

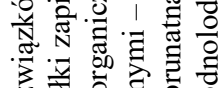

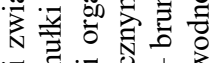

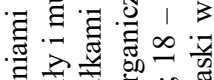

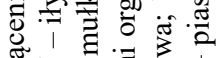

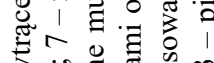

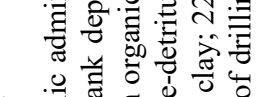

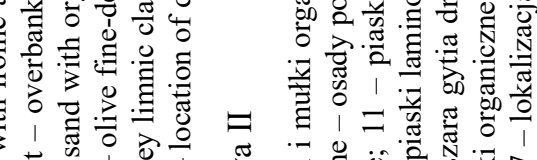

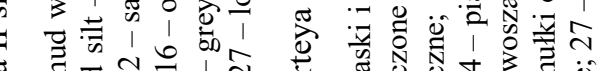

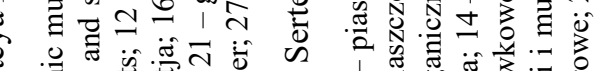

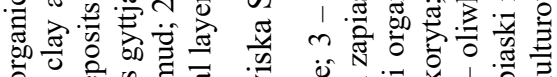

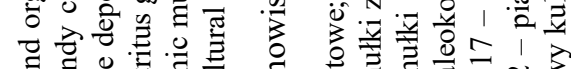

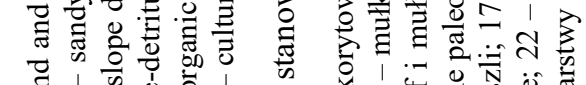
至人 1 क

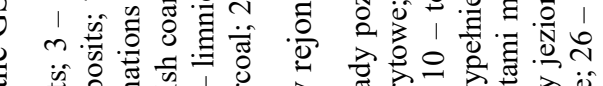

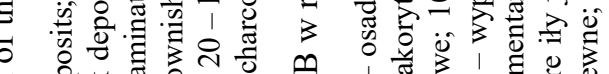

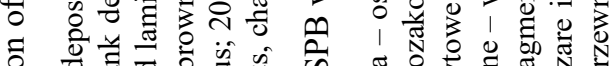

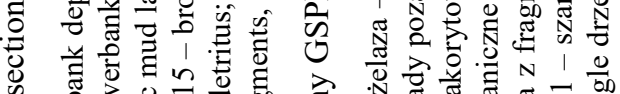

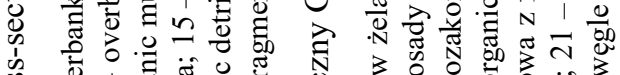
峁

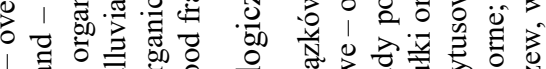

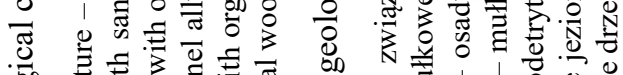

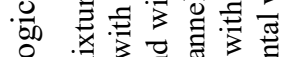

응

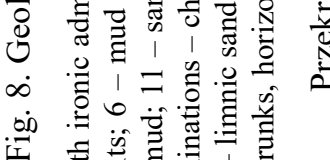

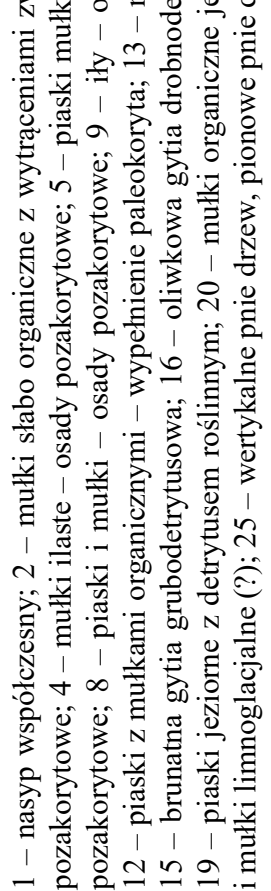




\section{Geological and geomorphological traits of the area}

The development of the Western Dvina River Basin was initiated after the last ice sheet recession. The territory lies within the recently glaciated area of the Weichselian (Valdai) Glacial (Velichko et al. 2011) (Fig. 1). The formation of terrain relief during the Valdai Glacial Stage depended on the geological features of the region (Markov 1961). The region is characterised by a mosaic of glacial and glaciofluvial landscapes with numerous lakes and wetlands, closed depressions and poorly developed valleys of small rivers. The main relief forms of the area are: moraine plateaus, moraine hills, glaciofluvial plains, subglacial channels, and kames, all formed during the Valdai Ice Sheet expansion, as well as Holocene river valleys and biogenic plains (partly within post-lake basins) (Fig. 2). Various deposits and soils occurred in different areas of the landscape. In the southern part, the moraine plateaus are covered by sandy till, while in the northern part the glaciofluvial plains are covered by sands with admixtures of gravels. In the Late Weichselian (Late Valdai) and during the Holocene, organic deposits of lacustrine and swamp origin, alluvial sands and silts accumulated. Slopes of the subglacial channel were cut by gullies in the Late Holocene (see Piech et al. 2018, in this issue).

The plateaus are incised by a distinct subglacial channel, which was drained later by the Serteyka River. Numerous widenings (basins) with biogenic plains and narrow gap sections in between occur in the valley floor. They are the remnants of palaeolake basins. Four post-lake basins occur within the researched section of the valley - from the upstream: The Great Serteya Palaeolake Basin (GSPB), The Rudnya Palaeolake Basin, The Nivniky Palaeolake Basin, the smallest, unnamed palaeolake basin (which expedition members called "The Banya Palaeolake Basin" and which was studied by Kalicki et al. 2015a). These basins are 100-600 metres wide and 100-2000 metres long. They are filled with organic deposits (mostly gyttjas) of up to 8 metres thick covered with sandy-silty overbank alluvia. All the basins are part of the present Serteyka River valley and are connected by narrow erosive segments (Kul'kova et al. 2001; Kalicki et al. 2015a; Kittel et al. 2016). Radiocarbon data sets and results of a preliminary pollen analysis prove that the sediments of the palaeolake basins hold records of the Late Weichselian and Holocene (Kul'kova et al. 2001, 2015b; Mazurkevich et al. 2009a, 2012; Tarasov et al. 2018). Potentially, the records of the Late Weichselian and Holocene also exist within deposits of kettle holes situated on glaciofluvial plains (Kittel et al. 2017).

The Serteyka River valley was formed in a subglacial channel, after palaeolakes were merged together. Two main palaeolake generations existed within the subglacial channel. The first stages of lake formation took place in the Late Weichselian within glacial crevasses and between blocks of dead ice. Inorganic deposits, mainly silts and sands accumulated at the bottom of these lakes. The remnants of the ice-melting lakes are sandy-silty kames and kame terraces. Kames formed low hills in the subglacial channel floor. In the Late Weichselian (according to the ${ }^{14} \mathrm{C}$ data set - see Tarasov et al. 2018 and also authors' materials), the lakes of the second generation started to develop after buried ice began to melt. They were filled with organic deposits and the water level depended on palaeoclimatic and palaeohydrological changes (Kalicki et al. 2015a; Kittel et al. 2016). The climatic conditions of the Serteya territory situated in a humid zone of high precipitation influenced lake development. Small and shallow lakes turned into swamps during the Holocene because of the high rate of accumulation of deposits. Fluvial systems could, however, replace part of the lake basins during the lakes' regression stages in the Mid- and Late Holocene (Kalicki et al. 2015a, b; Kittel et al. 2016).

The Serteyka River presumably drained subsequent water bodies during the Holocene. This drainage was an effect of fluvial headward erosion, as was confirmed by radiocarbon dating of the topmost parts of biogenic deposits. In the lowest section of the valley, the lake disappeared in the Late Vistulian-Holocene transition because the river had existed there since at least the Early Holocene. This is confirmed by a palaeochannel cut in the lacustrine sediments, and filled with organic deposits in the Middle Holocene. The Serteyka River presumably drained the Holocene lake basins, successively from the lower sector, as an effect of headward erosion, mainly during lake transgression phases. This is confirmed by radiocarbon dating of the very top parts of organic lacustrine deposits in subsequent post-lake basins (Kalicki et al. 2015a; Kittel et al. 2016). 


\section{Archaeology of the area}

Archaeological research has been conducted systematically in the Serteya region since the 1970s (Dolukhanov, Miklyaev 1986; Miklyayev et al. 1987; Dolukhanov et al. 1989; Mazurkevich 1995; Mazurkevich, Miklyayev 1998; Mazurkevich et al. 2009b). Over the last 30 years of long-standing archaeological research, numerous (ca. 60) archaeological camp sites and settlements were discovered in the lower, ca. 10kilometre-long section of the Serteyka River valley. The Serteya region of the Upper Dvina Basin was settled periodically from the Late Palaeolithic to the Middles Ages and more-orless permanent occupation of the area started in the Modern Period. Early medieval sites were surveyed in the Serteyka River and Western Dvina River valleys too. The region became part of the Grand Duchy of Lithuania in the late $14^{\text {th }}$ century, and later of the Grand Duchy of Moscow and the Tsardom of Russia. From 1582 to $1772 \mathrm{AD}$, it belonged to the Polish-Lithuanian Commonwealth, and in $1772 \mathrm{AD}$ the Serteya region became part of Russia.

Numerous archaeological sites are dated to the Neolithic; they are classified to this epoch based on pottery occurrence. The study reveals intensive settlement in the area during the Neolithic since ca. 8300 BP (Kul'kova et al. 2001; Mazurkevich et al. 2009a, b, 2012). The Neolithic remains were dated from $8000 / 7500$ to 3000 years BP (Mazurkevich et al. 2009a, b, 2012), and the processes of neolithisation were strongly dependent on climate changes - mainly vegetation season length, summer temperature and continentality (Kul'kova et al. 2015a). The sites are situated both on the mineral basement and within organic deposits of the biogenic plains formed in the area of a few palaeolake basins. The Early Neolithic sites were located at both lower and higher elevations, the Middle and Late Neolithic layers were located predominantly on lower elevations and even within lake deposits, which might be connected with ancient economic systems.

Of particular interest are Neolithic lake settlements, which were first discovered in the upstream basin of the Western Dvina River by A. Miklyaev in 1963. The first excavations were conducted in peat-bogs; it was only later that underwater excavations began. In the case of these sites, the organic artefacts and ecofacts remained in a very good state of preservation.
Early Neolithic communities were huntergatherers, while the Middle and Late Neolithic communities introduced agriculture and cattlebreeding (Mazurkevich et al. 2009a, b, 2012). However, due to palynological and archaeozoological analyses, this productive economy did not play a significant role in that period (Mazurkevich 2003; Mazurkevich et al. 2009b, 2012, 2016a; Tarasov et al. 2018).

\section{Archaeological characteristic and stratigraphy of the Serteya II site}

Different parts of the Serteya II site have been excavated thus far. Underwater archaeological excavations were conducted within its eastern part in the artificial canal made by drainage works in the 1980s (area of squares O-U/I-VII) (Fig. 9). The Neolithic cultural layers at the site were located within the lacustrine deposits mostly coarse-detritus gyttja. Vessel fragments attributed to the local Zhizhitsa Culture (ca. 3000-2200 BC), not limited numbers of stonemade tools (cf. Polkovnikova 2014), and wooden and bone objects were found in the cultural layer, which is rich in small burnt bones, fish bones, hazelnuts (sometimes also burnt), water chestnuts, acorns, animal bones and bird bones. Lots of organic artefacts and objects were found due to particularly good preservation conditions, including artefacts made from bone and antler as well as plant material. All the artefacts were found predominantly around the remains of wooden constructions and were mostly absent from the interiors of the constructions. Wicker baskets for waste recycling, nets, bast textile, fishing trap systems and campfires were also found at the site (Mazurkevich, Dolbunova 2011; Mazurkevich et al. 2011). Numerous piledwelling constructions have been recognised since 2009. Remains of construction №1 $\left({ }^{14} \mathrm{C}\right.$ dated to ca. 2400-2200 BC) occupy an approximately $24-\mathrm{m}^{2}$ surface. The construction walls were made from long, thin chips of $2-3 \mathrm{~cm}$ wide and $0.5 \mathrm{~cm}$ thick. Floor remains were represented by large wooden bark put on the poles and wooden planks and covered with sand in the fireplace (Photo 1, 2). Sites containing domestic structures (i.e. pile-dwellings), artefacts and ecofacts preserved within the lacustrine sediments in the research area are extremely important on a European scale. 


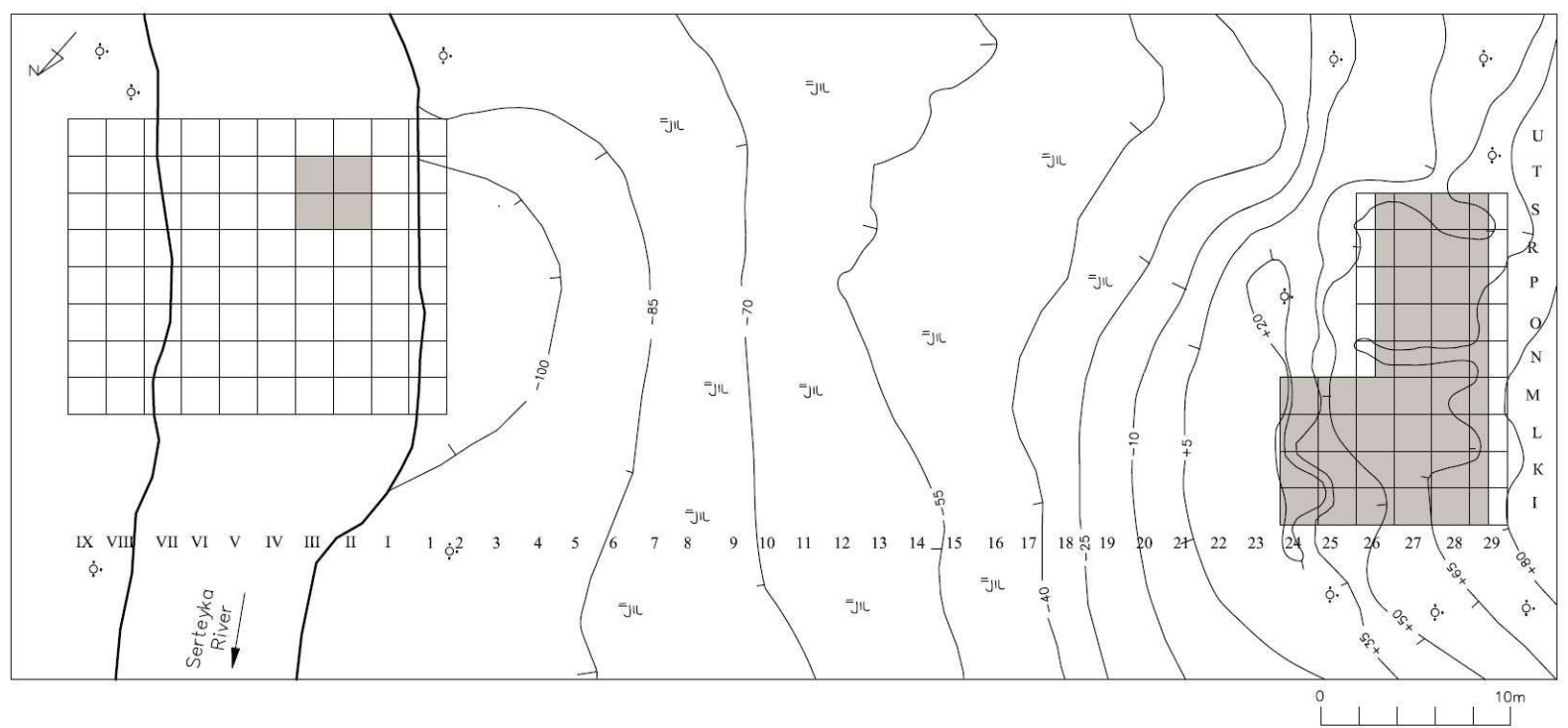

Fig. 9. Plan of the Serteya II site with excavated areas marked measuring network described with numbers and letters

Plan stanowiska Serteya II z zaznaczonymi obszarami eksploracji archeologicznej siatka pomiarowa oznaczona cyframi i literami

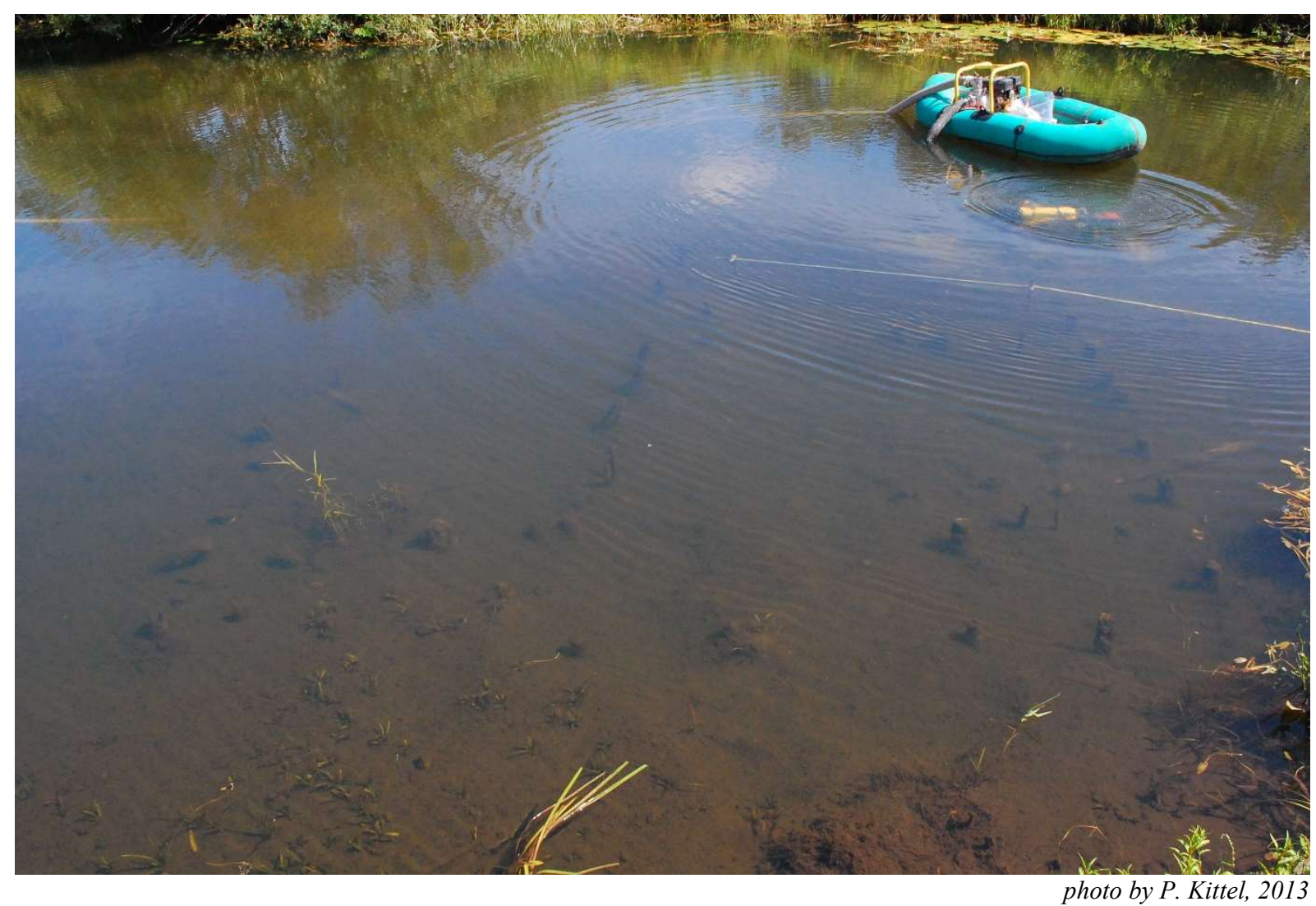

Photo 1. Remnants of the Late Neolithic pile-dwelling settlement at the Serteya II site

Relikty późnoneolitycznej osady palafitowej na stanowisku Serteya II 
A

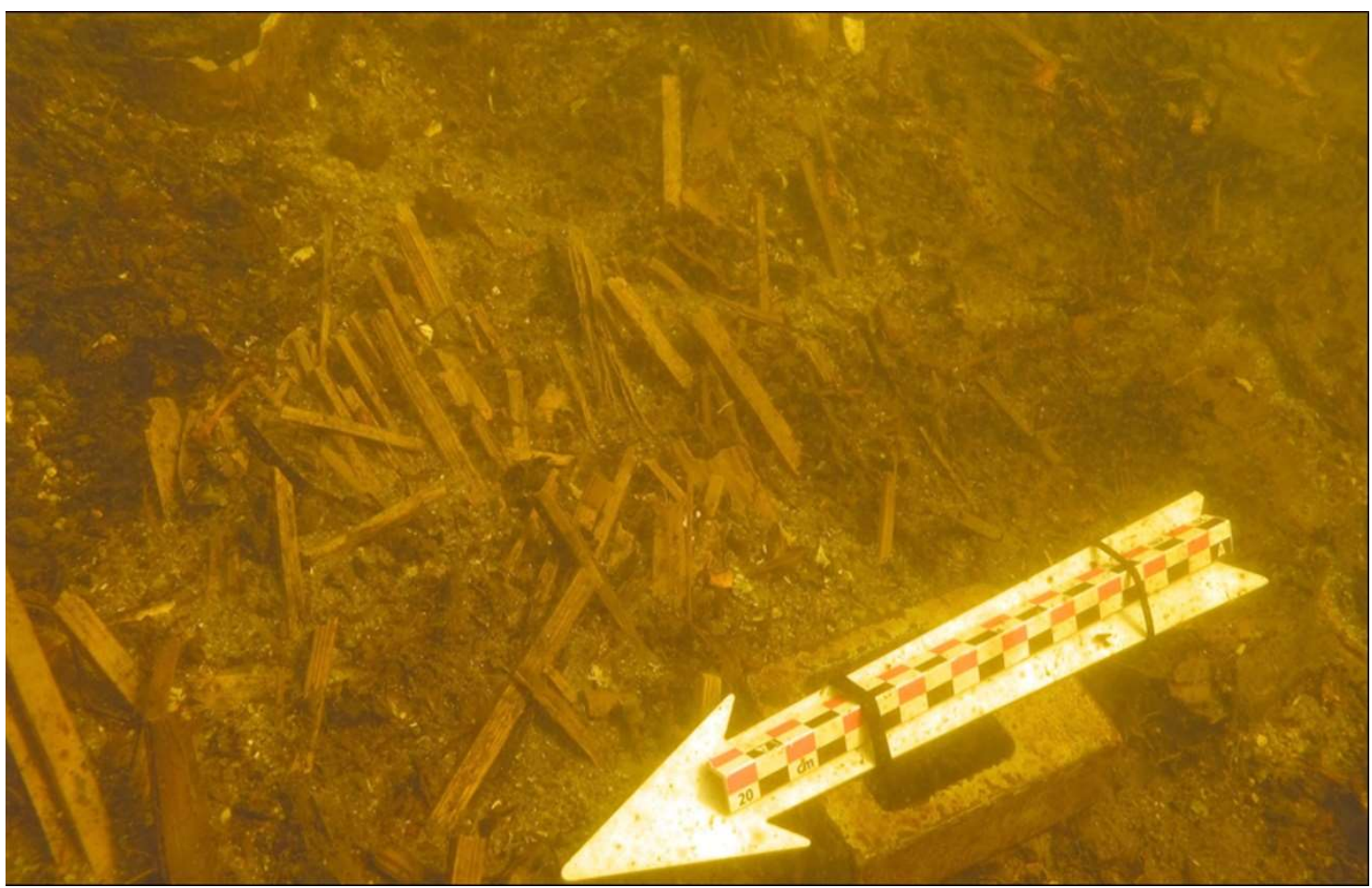

B

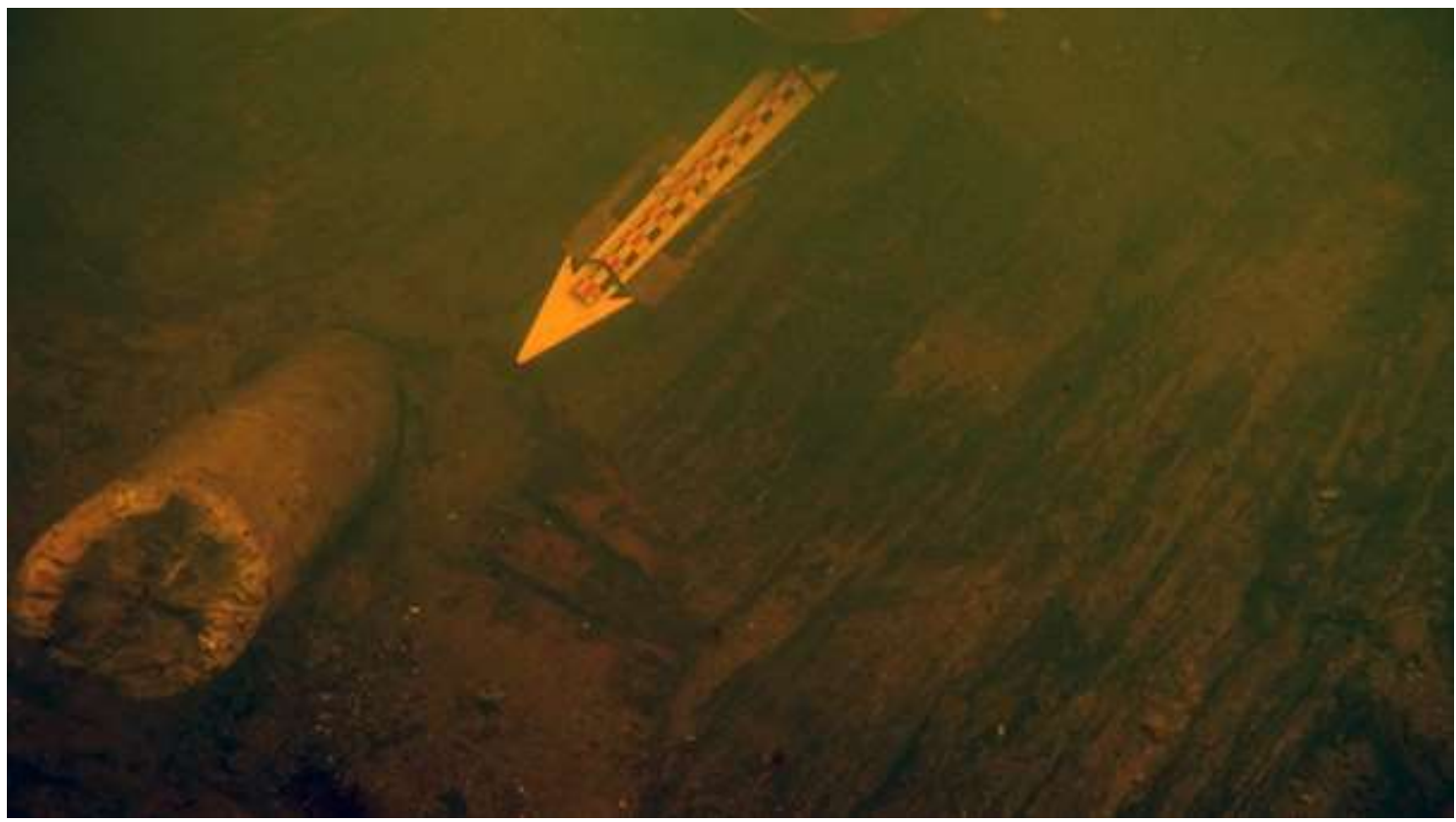

photo by A. Mazurkevich, 2014

Photo 2. Serteya II site. A - remains of the wall construction made from thin, treated wooden chips, $\mathrm{B}$ - remains of the floor of construction №1

Stanowisko Serteya. A - relikty konstrukcji ściany wykonanej z wąskich szczap drewnianych, B - relikty podłogi konstrukcji №1

The western part of the site, called Serteya II2 (squares I-S/24-29), and layer $\alpha$ (Fig. 9) are situated on the sandy ground and within the lacustrine deposits in the shore zone of the GSPB. Numerous artefacts and features were situated in: a brown coarse-detritus, a brown-olive coarse-de- tritus gyttja, and underlying sands with organic mud and clay admixture. The most ancient group of potsherds is represented by vessel fragments from the Serteya Culture dated to the $7-6^{\text {th }}$ millennium BC and the Rudnya Culture (53004900 BC). They were found within sands with 
organic mud and clay admixture. Selected plant macrofossils from organic mud lamination were ${ }^{14} \mathrm{C}$ dated to $9973 \pm 35 \mathrm{BP}$ (MKL-A3887), i.e. 9647-9334 BC. The potsherds found at the site are eroded, which could attest to redeposition of the cultural layer and organic matter in the lake shore zone. Fragments of the Rudnya Culture vessels were also found in a lower part of the gyttja layer and ${ }^{14} \mathrm{C}$ dated to $5368 \pm 28 \mathrm{BP}$ (MKLA3884), i.e. 4322-4084 BC. This suggests that this pottery could have been deposited due to the erosion of the cultural layer on the upper sandy slope.

The up-to-80-cm thick layer of brown and olive gyttja with wooden remains contains rich artefacts (mainly potsherds) and ecofacts. This gyttja layer was dated in the very bottom, as mentioned above, to $5368 \pm 28$ BP (MKL-A3884), i.e. 4322-4084 BC and in the top to $3371 \pm 21 \mathrm{BP}$ (MKL-A3936), i.e. 1687-1637 BC (Photo 3, 4). Various pottery types were recorded in this layer, which are attributed to different cultural and chronological periods. They include vessels attributed to Eneolithic cultures of the steppe and foreststeppe zone of Eastern Europe: thick-edged Khvalynskaya Culture pottery and vessels of the late stage of the Sredny Stog Culture, which existed from the $5^{\text {th }}$ to the beginning of the $4^{\text {th }}$ millennium BC.

The majority of finds were found in the upper part of the brown gyttja layer with wooden remains, as well as in olive gyttja. The Middle Neolithic was represented by materials of the Usviaty Culture (3100-2900 BC), deposited mostly in an olive gyttja layer. Most typical for these deposits are potsherds of the Zhizhitsa Culture (3000-2300 BC) - as for the piledwelling part of the site. Nevertheless, a small group of pottery, which might have been formed under the influence of the Linear Pottery Culture, and potsherds dated to the end of the Early Neolithic were discovered in gyttja. Apart from the potsherds, some flint, bone, antler and wooden artefacts were found. The remnants of a rectangular construction with an accumulation of elk, bear, badger and boar bones were recognised in the bottom of the brown coarse-detritus gyttja layer and might be connected with the Zhizhtsa Culture communities. This may have been a place dedicated to the butchering of animals (Mazurkevich et al. 2016c, 2017b).

In this part of the site, two almost complete skeletons of young women deposited in nonanatomical order and a small part of a third skeleton were registered. The bones were found in brown coarse-detritus gyttja with rich wood fragments (Photo 5, 6; Fig. 10). The corpses had probably lain on wooden branches on the surface for a long period. The gyttja from the horizon close to the skeletons was ${ }^{14} \mathrm{C}$ dated to $3967 \pm 33$ (MKL-A 3979), i.e. 2566-2462 BC. However, two wooden elements in the immediate surroundings of the bones were dated to $3760 \pm 20$ BP (Лe-11161), i.e. 2202-2142 BC and 3450 \pm 50 BP (Лe-11162), i.e. 1876-1691 BC (Mazurkevich et al. 2017b). The wooden elements were most probably deposited during a palaeolake transgression phase.

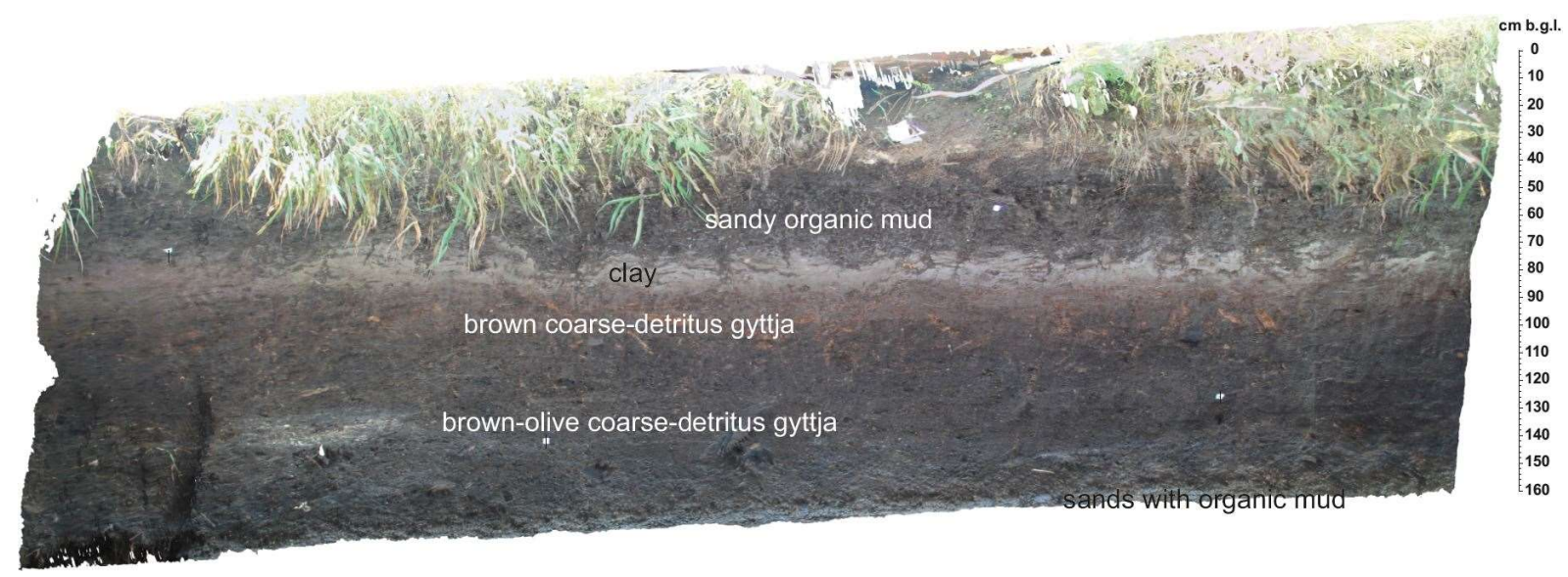

photo by P. Kittel, 2016

Photo 3. Wall of the exposure (the M/25 square) in the GSPB shore zone at the Serteya II site Ściana wykopu (odcinek M/25) w strefie brzegowej GSPB na stanowisku Serteya II 


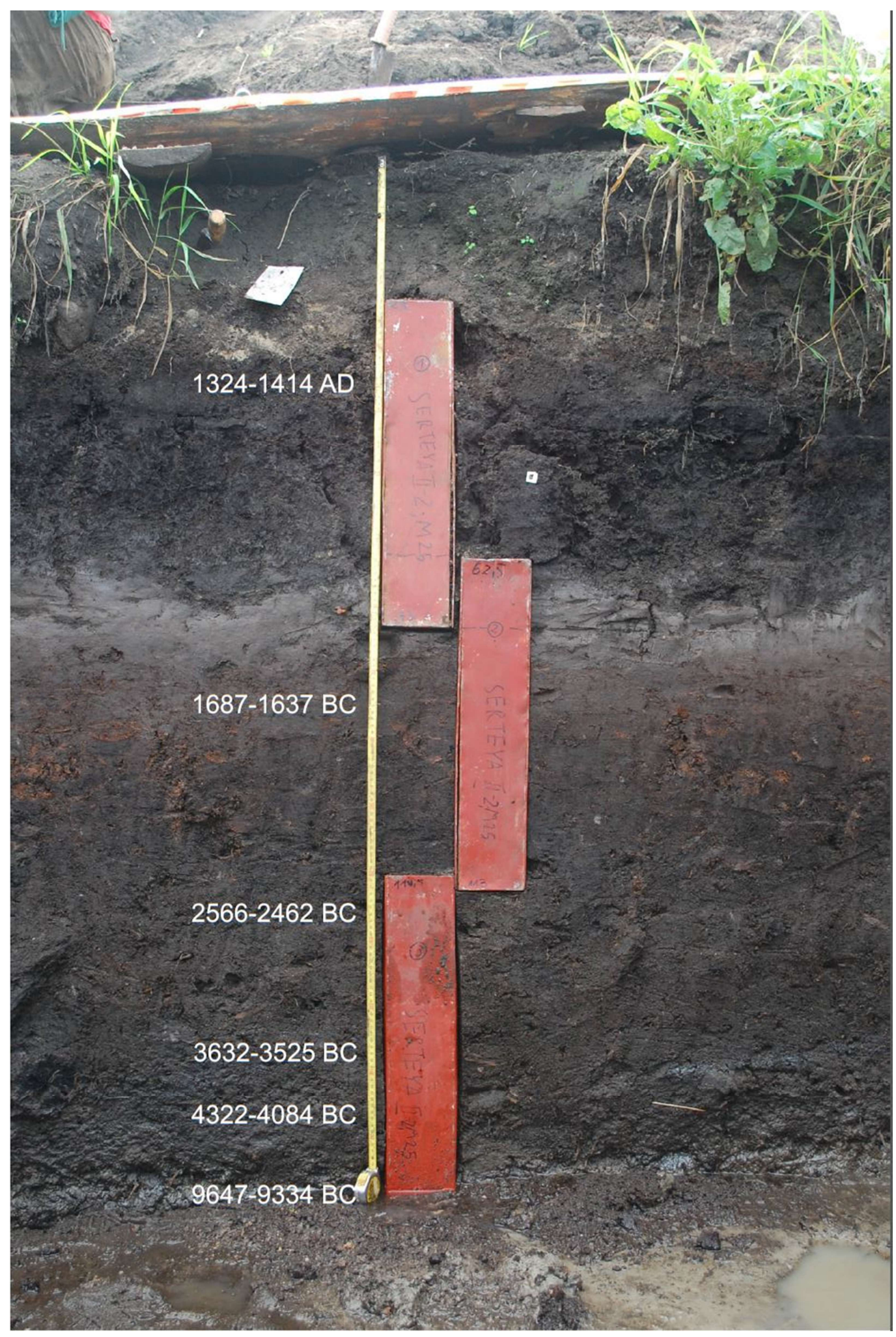

photo by A. Mroczkowska, 2016

Photo 4. Core of organic deposits in the wall of the exposure (the $M / 25$ square) in the palaeolake shore zone at the Serteya II site

Rdzeń osadów organicznych w ścianie wykopu (odcinek M/25)

w strefie brzegowej paleojeziora na stanowisku Serteya II 


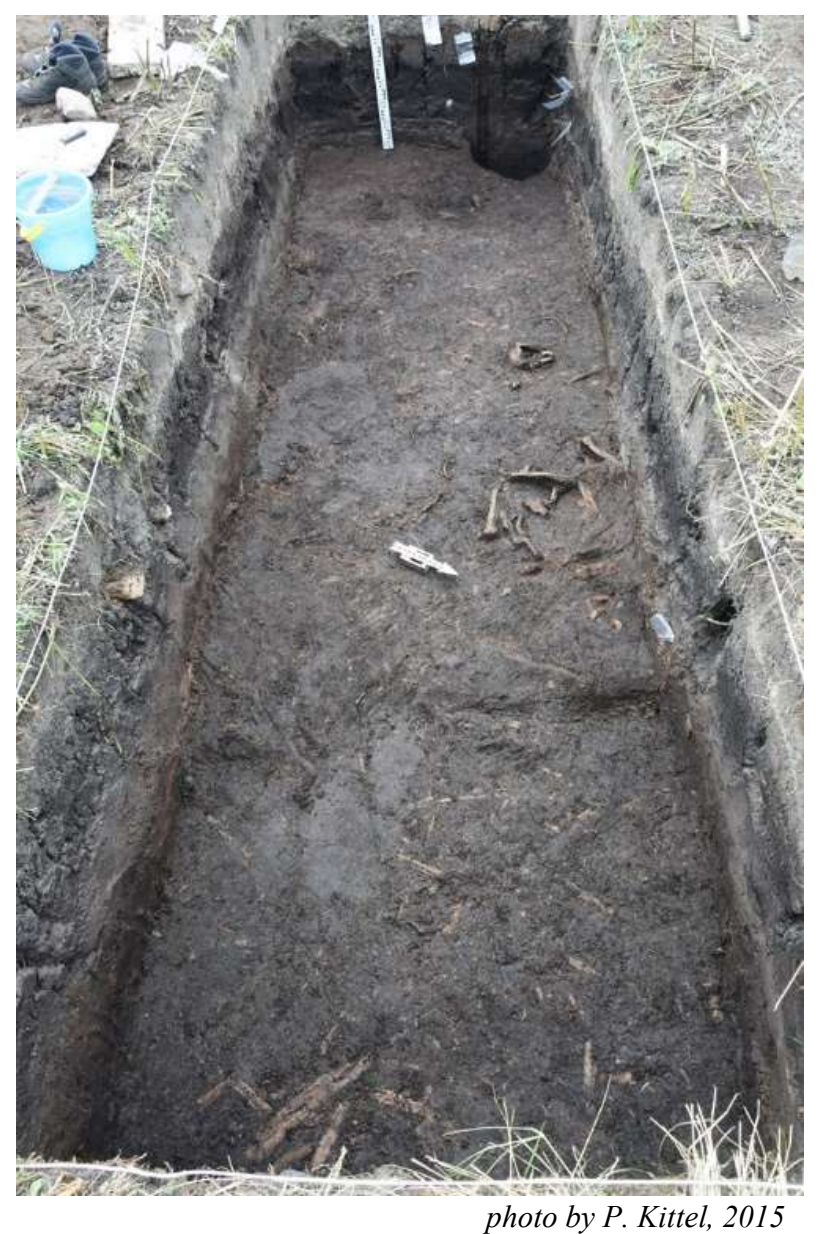

Photo 5. Human bones in the geological outcrop at the Serteya II site

Kości ludzkie w odkrywce geologicznej na stanowisku Serteya II

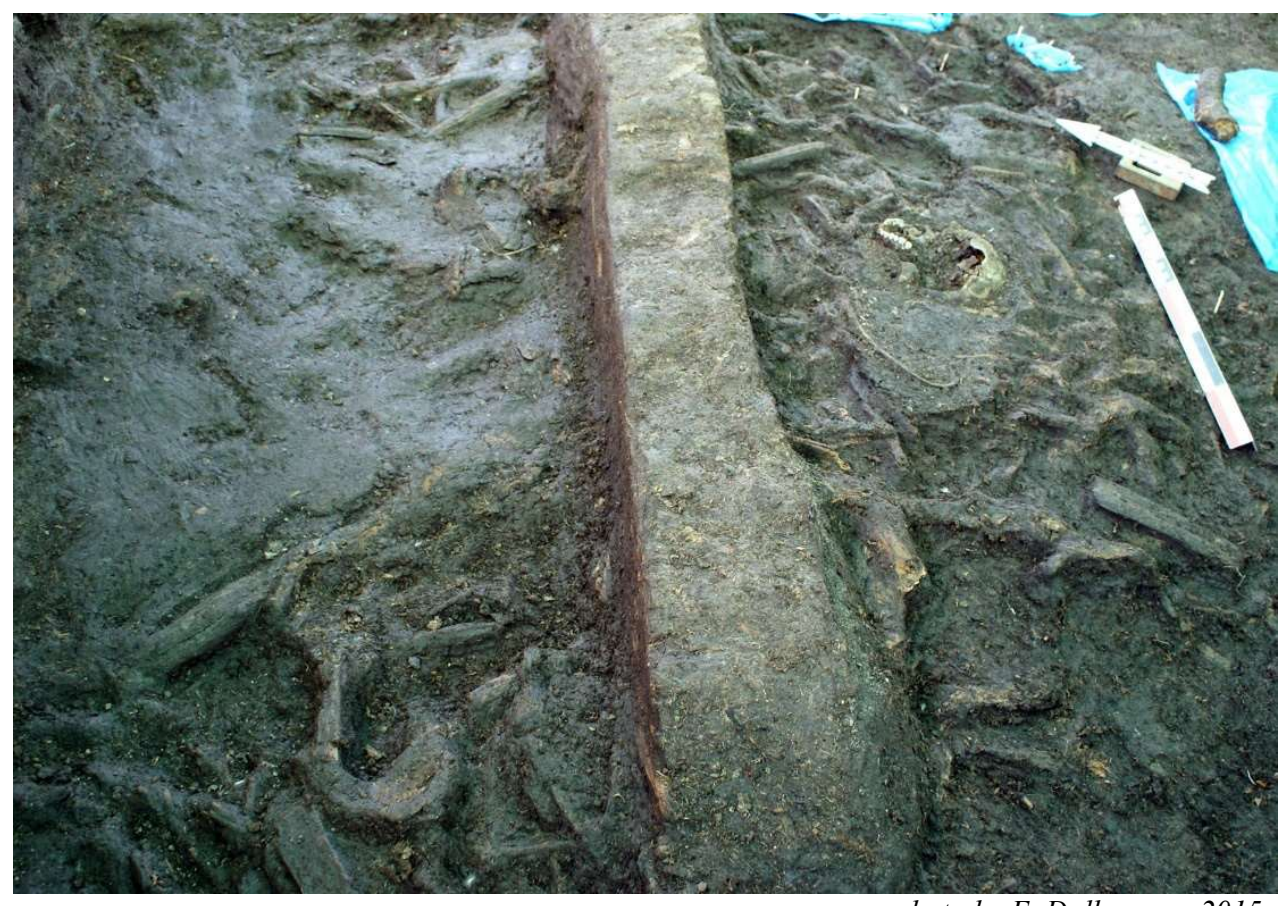

photo by E. Dolbunova, 2015

Photo 6. Remains of skeletons within wooden branches in the brownish coarse-detritus gyttja at the Serteya II site

Pozostałości szkieletów pośród elementów drewnianych w brunatnej gytii grubodetrytusowej na stanowisku Serteya II 


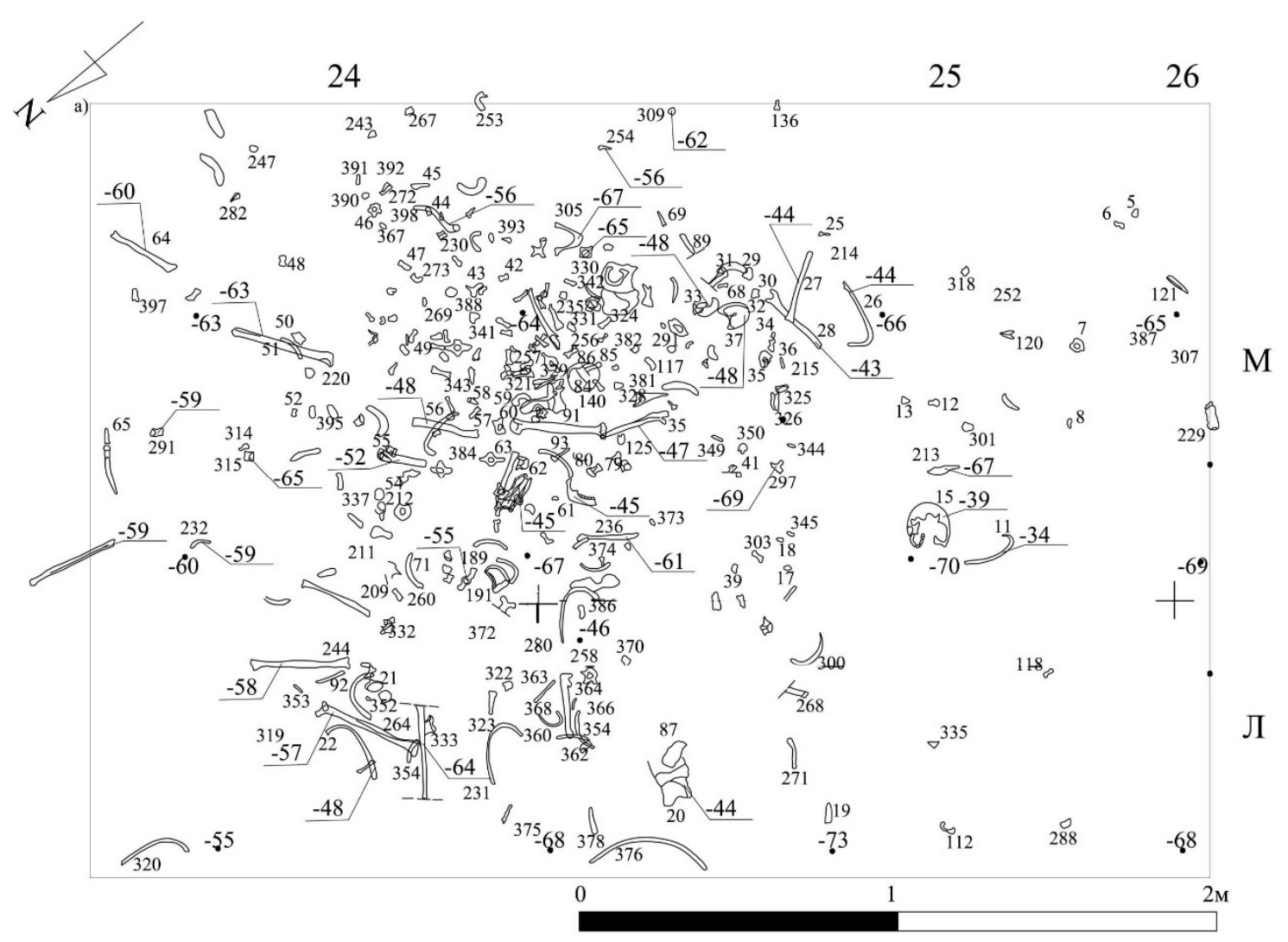

Fig. 10. Serteya II site - distribution of human bones

Stanowisko Serteya II - rozprzestrzenienie kości ludzkich

\section{Geological and geomorphological situation of the Serteya II site}

The geomorphological research based on detailed geological mapping and the results of geophysical and topographical survey revealed the main relief forms of the lower part of the present-day Serteyka River valley and its surroundings, as well as recording the thick organic deposits series that fill palaeolake basins and river deposits within post-lake basins. The former coring records (see: Zajceva et al. 2003; Tarasov et al. 2018) and the results of geological mapping prove that the GSPB in the Serteya II site's immediate surroundings is filled with organic deposits (mostly gyttja) of up to 4.5 metres thick and inorganic lacustrine deposits (silt and clay) of up to ca. 7.5/8.0 metres.

The palaeoecological studies undertaken in this project focused on two cores of organic deposits from the Serteya II site area. The core ST IIa, taken from the central part of the site (Fig. 3A), covers $7.8 \mathrm{~m}$ of sediments with approx. $4.5 \mathrm{~m}$ of organic deposits (mostly various types of gyttjas) and, as confirmed by previous radiocarbon da- ting elaborated for the adjoining profile, it encompasses the Late Weichselian and the Holocene up to ca. 1000 BP. For a better understanding of lake level fluctuations, a trench was excavated in the palaeolake shore zone. A second, 1.4-m-long core (STII M25) of organic deposits was collected from the wall of a trench of depth up to $160 \mathrm{~cm}$ below ground level. The core was taken from where the skeletons were found. The profile presents four lithological units: $23-63.5 \mathrm{~cm}$ b.g.l. - organic mud; 63.5-75 cm b.g.1. - loam; 75-148.5 cm b.g.1. coarse detritus gyttja; and $148.5-160 \mathrm{~cm}$ b.g.l. sand with organic mud and plant detritus (Photo $3,4)$. Both cores contain the cultural layer of the Serteya II site.

The GPR profile 62-63 passed through the western part of the geological cross-section (Fig. $3 \mathrm{~A})$. The upper part of the section is represented mainly by gyttja and peat with organic mud (Fig. 3B). Below, the limnic sand with organic detritus and limnic organic mud was detected, the roof of which decreases steeply eastward. The GPR survey allowed the boundary between gyttja and sand to be traced to a depth of 3 metres. Due to the considerable attenuation of the electromagnetic signal in gyttja, the lower sediments 
were not analysed. In the central part of the geological cross-section, according to the drilling data, a system of palaeochannels was found formed by sand and organic mud and also gyttja. Palaeochannels can also be traced on radiograms - they correspond to areas with a high-amplitude signal and intense coherent line-ups. All of the palaeochannels are stretched in one direction and are adjacent to each other. GPR data allow us to determine not only the size and location, but also the shape of the palaeochannels. In the lower part of the GPR section the top of the till is traced, rising in the eastern part of the profile and opened there by boreholes.

On the radarogram along the parallel profile through points 107-108-109, located to the south of profile 62-63, the same palaeochannels of the Serteyka River were traced. Layered sand deposits also occur to the north of the profile through the drilling points, but lacustrine deposits rich in organic matter are more widespread there.

In the Serteya II site area, it was interesting to estimate the thickness of the lacustrine sediments and to trace their contact with the underlying deposits. According to the GPR data, the thickness of gyttja is minimal in the area of the excavation (less than $2 \mathrm{~m}$ ), and increases to the north (GPR section of profile 59-125) and south (GPR section of profile 118-122) of it (Fig. 3B). In the northern part, clay has been found below the gyttja, as was demonstrated with a wave pattern. In the southern part, there are crosslayered sands under gyttja and also clay under that. Thus, the river sandy deposits in this area are to the south of the excavation site and are wedged out around it.

Remains of pile-dwellings were discovered within coarse detritus gyttja at the elevation of ca. 150.5-151.2 $\mathrm{m}$ a.s.l. During augering of the part of the site close to the canal, two cultural layers were documented: 1/ ca. 1.2-1.5 and 2/ ca. $2.0 \mathrm{~m}$ b.g.l. (Fig. 8). The constructions were situated on a marshy shore or an exposed lake bottom. This is attested to by the accumulation of clay, sand and shells around the piles. So, the piles must have been located on a dry surface and seasonal water rises led to the penetration of clay and cultural layer into spaces around the piles. Pits filled by different waste products were also traced in the underlying layer. Accumulations of waste products show that they could have been submerged and eroded during water level increases. Cultural remains (artefacts and ecofacts) were accumulated on the gyttja surface during dry periods (regression phases), and later they were sunken and covered with gyttja deposition. The archaeological context suggests episodes of lake regressions, allowing the appearance of settlements on the post-lake plains.

In the western part of the site, within the palaeolake shore zone, the skeletons were situated at an elevation of ca. 152.0-152.25 m a.s.l. in the brown coarse-detritus gyttja. Below, in the brown and olive coarse-detritus gyttja, a cultural layer was recorded at a depth of ca. 120-150 cm b.g.l. (ca. $151.8-151.5 \mathrm{~m}$ a.s.1.) with rich Middle and Late Neolithic artefacts and ecofacts (Photo 3 ). Early Neolithic materials were found mostly within sands with organic mud laminations up to $160 \mathrm{~cm}$ b.g.l. (elevation ca. $151.4 \mathrm{~m}$ a.s.1.) in the deepest part of the excavated area. In the most western part of the site, Neolithic features were excavated on the slope of the kame. This surface is slightly inclined to the ENE and formed by glaciofluvial sands with admixtures of gravels and limnoglacial fine sands and silts. The elevation of this area is from 153 to $157 \mathrm{~m}$ a.s.l.

\section{Discussion}

The radiocarbon data set and the results of a preliminary pollen analysis prove that the lacustrine sediments in the Serteya II site area hold records of the Late Weichselian and the Holocene (up to the Modern Period) (Kul'kova et al. 2001, 2015a, b; Mazurkevich et al. 2009a, b, 2012; Tarasov et al. 2018). However, numerous inversions were observed within this radiocarbon data set (see: Zajceva et al. 2003; Tarasov et al. 2018). The first palaeoecological reconstructions in the Serteya microregion were conducted in the 2000s (see: Kul'kova et al. 2001; Mazurkevich 2003; Kul'kova, Savel'eva 2003; Zajceva et al. 2003; Dolukhanov et al. 2004; Kul'kova 2005, 2006; Mazurkevich et al. 2009a, b; Tarasov et al. 2018). The cores of organic deposits from GSPB, The Rudnya Palaeolake Basin and The Nivniki Palaeolake Basin were studied in order to enable a palaeoenvironmental reconstruction with the use of pollen, diatom and geochemical analyses. These studies documented the subsequent lake level fluctuations in the Subboreal period as a result of climatic (mostly precipitations) fluctuations (Kul'kova et al. 2001). A decrease in precipitation was recorded for the early Subboreal period and, later, warming began in the Middle Subboreal. An increase in cooling and humidity was registered in the late Subbore- 
al period in the western Russian territory (Aleshinskaya, Spiridonova 2000). In the Subboreal period spruce became the base forest species in the Serteya region (Kul'kova, Savel'eva 2003). Productivity of the lake decreased and the water level was higher (Kul'kova et al. 2001). The Subatlantic period was cooler, with higher human impact at the beginning of the period. It was a time when most of the lakes turned into swamps. In the middle Subatlantic, human impact decreased. The main lake transgressions correlated with the humid stage of the Holocene (Kul'kova, Savel'eva 2003; Mazurkievich et al. 2012). During the Middle Holocene, the periphery of wetlands was forested by broadleaf forests. Charcoals derived from those species predominate in the Neolithic cultural layers buried in the lacustrine deposits (Kul'kova et al. 2001; Mazurkevich et al. 2009a, b; Tarasov et al. 2018).

The exceptional importance of the palaeoecological reconstruction of the local environment concerns the palaeohydrological conditions (transgression and regression phases) of the GSPB at the pile-dwelling Serteya II site in the Neolithic. The palaeohydrological conditions, the palaeolake evolution and the fluvial regime of the Serteyka River were the forces driving lake water table fluctuations, and determined the development of pile-dwelling settlements there. The crucial issue is the location conditions of the pile-dwelling constructions, and whether they developed during lake transgression or regression. Preliminary results of palaeoecological reconstructions document a lake water level regression during the Neolithic occupation phase. The pile-dwellings were situated directly on the surface of lacustrine deposits (coarse detritus gyttja) within the GSPB. The archaeological data, as pits dipped in the palaeolake bottom, suggest at least short-lasting regressions of water level during the existence of constructions (Mazurkevich et al. 2016b). The question remains: did the settlement emerged during the seasonal water level decrease, the short time of the lake regression, or after the permanent lake water disappearance associated with the Serteyka River valley development?

The situation recognised on the east side of the Serteya II site shows possible periods of the lake system being replaced by a fluvial one in the $2^{\text {nd }}$ half of $3^{\text {rd }}$ millennium BC. During hand augering and georadar prospections, fluvial deposits (channel alluvia and palaeochannel fills) were recorded within lacustrine deposits and ${ }^{14} \mathrm{C}$ dated to: $3950 \pm 70$ BP (MKL-3095), 2569-2343 BC; 3670 \pm 120 BP (MKL-3094), 2272-1888 BC; 3570 \pm 40 BP (MKL-3092), 2010-1881 BC or even 2680 $\pm 90 \mathrm{BP}$ (MKL-3093), 972-786 BC (Figs 7, 9). On the opposite side of the GSPB (ENE from the Serteya II site point of view), a small river valley was developed that cut the subglacial channel slope. Within the GSPB, a well-developed alluvial fan was formed. Delta sediments interfinger with lacustrine deposits.

The landscapes and resources that were formed in the studied area mostly during the Middle Holocene attracted not only hunterfisher communities, but also members of cultures with a cattle-breeding and agriculture economy. These cattle-breeding tribes penetrated the Upper and Middle Dvina basin, as well as the Smolensk part of the Dnepr River basin in the $5^{\text {th }}$ millennium BC from the southern foreststeppe, and later on - in the $3^{\text {rd }}$ millennium BC (bearers of cultural traditions of Globular Amphora Cultures and Corded Ware Culture). Climate aridisation in the southern regions of Eastern Europe led not only to vegetation zones shifting to the north, but also to intense migration processes. As a result of migrations in the region in question, tribes of the Eneolithic cattle breeders appear, which are marked by a specific pottery and stone industry. It was probably the vast flood plains of the lacustrine-river systems in Serteya area that attracted these early cattlebreeding communities.

Analysis of sites' distribution within the reconstructed Subboreal landscapes allows some distinctive features to be determined. The resources that maintained the life of the piledwelling settlement throughout the year had to be used according to some strategy. This strategy might have included various factors - accessibility of resources, the ceasing of some of them, their maintenance and renewal through time, the choice of place for permanent and temporal settlements/sites according to some factors, etc. Seasonality and the time period of site occupation were also important factors conditioning the availability and amount of different resources.

Accessibility of and distance to different resources might have changed over time or depending on season. The use of spruce as a building material disappeared after a while near the site, thus the distance to this resource increased greatly. Activities in forests can also be traced through single finds of stone axes of the Middle to Late Neolithic. Seasonality and some strategy 
in hunting different animals (primarily the most meaty one - the elk) may also be noted based on faunal remains. The finding of only parts of carcasses of big animals on the site may be evidence of the area where the animals were caught having been remote. The small number of species recorded, which could not have supplied the needs (in meet, raw materials for tools production, and skins) of the inhabitants of this site throughout the whole period of its existence, would evidence the existence of other places where butchering was conducted. Single scrapers and arrowheads attributed to this time found in different parts of the GSPB and other palaeolake basins may indicate temporal hunting and butchering sites or "satellite-sites" serving this permanent pile-dwelling settlement. Pottery similar to that of the Serteya II site and remains of bones marking a butchering zone were found on contemporaneous sites Serteya X and VIII (Fig. 4). The remains of household constructions (without fire places) on the Serteya X sites may evidence the existence of special storage and butchering places $500 \mathrm{~m}$ from a basic settlement. They were located on the islands and shores of the lake.

Fishing and gathering products might have been the basis of the diet during spring and the beginning of autumn, and hunting from autumn to spring. Cattle-breeding and agriculture have not yet become the main source of food supply. Single bones of domesticated horse, cow, sheep and probably pig were found on the sites of this region (Sablin, Siromyatnikova 2009). Palynological data might indicate some agricultural activities as well (Dolukhanov et al. 2004; Arslanov et al. 2009). The harvesting and storage of wood for building might have been the most effective during the winter period, because of wood quality at this time, and ease of transportation. Wood for nets, ropes, textile, baskets and other basketry would most reasonably have been conducted during spring because of material quality.

Archaeological and geoarchaeological study of the Serteya II site allowed the reconstruction of different zones of inhabitation and household activities related to the GSPB marshy area (central part of the pile-dwelling site), a shore part with other types of constructions and butchering zones: all zones were probably in use during the lifetime of the pile-dwelling Serteya II site in the $3^{\text {rd }}$ millennium BC. The Serteya II pile-dwelling settlement appeared before the 4200-years-BP cooling event (Mazurkevich, Dolbunova 2011;
Mazurkevich et al. 2014). The archaeological context, as well as palaeoecological data, suggests the presence of short-term episodes of lake regressions in this period, allowing the piledwelling settlement's development on post-lake plains. The settlement survived for numerous seasons before being flooded again (Mazurkevich, Dolbunova 2011; Mazurkevich et al. 2011; Kul'kova et al. 2015a, b).

\section{Conclusions}

In the long period during the Holocene, few lake basins existed within the present-day Serteyka River valley. One of the largest, the Great Serteya Palaeolake Basin (GSPB) occurred in the area of Serteya II site. The Serteyka River presumably drained subsequent lake basins in the Holocene, successively from the lower sector, as an effect of headward erosion. These processes took place mainly during lake transgression phases. A fluvial system also replaced part of the lake basins during regression phases in the Late Holocene. Water level fluctuations strongly influenced the human settlements - during the regression phase it was possible to situate the pile-dwelling constructions on the uncovered lake bottom, although they were flooded in the transgression phase. Settlement density strongly depended on climate and vegetational changes, which influenced the availability of natural resources. The environmental conditions seem to be very attractive - especially to Late Neolithic communities - in regression phases, due to a high level of landscape geo- and biodiversity, including small lakes, rivers and fertile hydrogenic and semihydrogenic soils. Therefore, the most important issue concerns palaeoclimatic and palaeoenvironmental changes and their influence on ancient communities, such as the phenomenon of the emergence of the culture of pile-dwellers.

The palaeoenvironmental research contributes greatly to broadening the knowledge of the functioning and transformation of the natural environment in the Neolithic, mainly during the transition from the hunter-gatherer economy into the productive one, and also during the period of global climate changes ca. 6200 and 4200 BP. Pile-dwellings appeared in the end of the $4^{\text {th }}$ to the beginning of the $3^{\text {rd }}$ millennium $\mathrm{BC}$ (ca. $4900 \mathrm{BP}$ ), in the period of rebuilding of ecological niche forced by environmental changes in the transition of the Atlantic to the Subboreal. It is 
supposed that the new type of architecture (i.e. pile-dwellings) was a form of adaptation to the changeable ecological conditions of the Subboreal Period. The variable geomorphological system (changeably: fluvial and lacustrine or swampy) strongly determined the lifestyle and economy of Neolithic pile-dwelling settlers.

\section{Acknowledgments}

The palaeoecological research at Serteya II site is financed by grants from the "National Science Centre, Poland" based on the decision No. 2017/25/B/ HS3/00274.

We would like to thank Prof. M. Krąpiec for radiocarbon dating.

The authors are grateful the Reviewers and Editors of AGL for their very constructive remarks which greatly improved the final version of the paper.

\section{References}

Abramov L.S. 1972. Opisaniya prirody nashey strany: Razvitiye fiziko-geograficheskikh kharakteristik. Mysl'. Moskva.

Aleshinskaya A.S. Spiridonova E.A. 2000. Periodizatsiya epokhi bronzy lesnoy zony evropeyskoy Rossii. Tverskoy Arkheologicheskiy Sbornik 4(1): 52-358.

Arslanov Kh.A., Dolukhanov P.M., Savelieva L.A., Dzinoridze E.N., Kuzmin G.F., Denisenkov V.P. 2009. The Holocene Environments in North-Western and Central Russia. In: P.M. Dolukhanov, G.R. Sarson, A.M. Shukorov (eds) The East European Plain on the Eve of Agriculture. BAR International Series 1964. Archaeopress, Oxford: 109-121.

Dolukhanov P., Mazurkevich A. 2000. Sites lacustres neolithiques de Russie, Archeologia 369: 6970 .

Dolukhanov P.M., Miklyayev A.M. 1986. Prehistoric lacustrine pile dwellings in the north-western part of the USSR. Fennoscandia Archaeologica 3: 81-89.

Dolukhanov P.M., Gey N.A., Miklyayev A.M., Mazurkewicz A.N. 1989. Rudnya-Serteyska, A stratified dwelling-site in the upper Duna basin (a multidisciplinary research). Fennoscandia Archaeologica 6: 23-27.

Dolukhanov P., Shukurov K., Arslanov A.N., Mazurkevich L.A., Savel'eva E.N., Dzinoridze M.A., Kulkova M., Zaitseva G.I. 2004. The Holocene Environment and Transition to Agriculture in Boreal Russia (Serteya Valley Case Study). Internet Archaeology 17 (http://intarch.ac.uk/journal/issue17).

Gorlach A., Kalm V., Hang T. 2015. Thickness distribution of quaternary deposits in the formerly glaciated part of the East European plain. Journal of Maps 11(4): 625-635.

Kalicki T., Alexandrovskiy A.L., Kittel P., Krupa J., Mazurkevich A., Pawłowski D., Płóciennik M., Stachowicz-Rybka R. 2015a. From Lake Basins to River Valley - Late Vistulian and Holocene Evolution of Last Glaciation Area: Serteya Basin (Western Russia). International Association of Geomorphologists (IAG) Regional conference "Gradualism vs catastrophism in landscape evolution", July 2-4, 2015. Publishing House of Altai State University, Barnaul: 159-161.

Kalicki T., Kittel P., Pawłowski D., Płóciennik M., Stachowicz-Rybka R., Mazurkevich A., Krupa J., Alexandrovskiy A. 2015b. Postglacial evolution of Lower Serteya river valley (Western Russia). Quaternary Conference, 27 November 2015. ÚGV PřF MU, Brno: 23.

Kazakov E.E. 2016. Opyt organizatsii byudzhetnoy topograficheskoy aerofotosyemki v usloviyakh polevoy ekspeditsii sredstvami lyubitelskogo BPLA DJI Phantom 3 Advanced. GISLab.info (http://gis-lab.info/jaa/aerial_photo_DJI Phantom_3.html)

Kittel P., Mazurkevich A., Dolbunova E., Kalicki T., Kul'kova M., Pawłowski D., Płóciennik M., Stachowicz-Rybka R., Zaitseva G. 2016. Evolution of lake basins in the Serteya region (Western Russia) in the context of Neolithic settlement's development. Proceedings of the International Conference "Paleolimnology of Northern Eurasia. Experience, Methodology, Current Status", Yakutsk. 22-27 August 2016. North-Eastern Federal University, Yakutsk: 13-15.

Kittel P., Mazurkevich A., Błaszczyk K., Dolbunova E., Gauthier E., Kotrys B., Kramkowski M., Lamentowicz M., Łuców D., Mroczkowska A., Płóciennik M., Słowiński M. 2017. Last 1000 years palaeoecological history of the kettle-hole peatland in the Serteya region (research project). / Kittel P., Mazurkevich A., Blashchik K., Dolbunova E., Got'ye E., Kotrys B., Kramkovski M., Lamentovich M., Lutsuv D., Mrochkovska A., Plutsennik M., Slovin'skiy M. 2017. Paleoekologicheskaya istoriya poslednikh 1000 let torfyanikovoy kotloviny $\mathrm{v}$ Serteyskom regione (predstavleniye proyekta). In: A.A. Vybornov, A.N. Mazurkevich, E.V. Dolbunova, E.S. Tkach (eds) Kul'turnyye protsessy $v$ tsirkumbaltiyskom prostranstve $v$ rannem $i$ srednem golotsene. MAE RAN, Sankt-Peterburg: 50-54.

Kondracki J. 1992. Fizycznogeograficzna regionalizacja republik Litewskiej i Białoruskiej w układzie dziesiętnym. Przegląd Geograficzny 64(34): 341-346

Kul'kova M.A. 2005. Geokhimicheskaya indikatsiya landshaftno-paleoklimaticheskikh usloviy $\mathrm{V}$ 
golotsene v regionakh Dvinsko-Lovatskogo mezhdurechia i Yuzhnoy Sibiri. Avtoreferat dissertatsii. Sankt-Peterburg.

Kul'kova M. 2006. The geochemical indicators of paleoclimate of Holocene and their meaning for reconstruction of prehistory sites in Western Dvina-Lovat' area of North-Western Russia. Proceeding from the 8th Nordic Conference on the Application of Scientific Methods in Archaeology "Archaeology and Environment". Umee 21: 93-100.

Kul'kova M.A., Savel'eva L.A. 2003. Vosstanovleniye paleoklimaticheskikh usloviy golotsena $\mathrm{V}$ rayone zabolochennykh ozer v doline r. Serteyki v Velizhskom rayone Smolenskoy obl. po dannym sopryazhennogo analiza. Drevnosti Podvinia. istoricheskiy aspekt: po materialam kruglogo stola. posvyashchennogo pamyati A.M. Miklyayeva. 6-8 oktyabrya 1999 g. Gosudarstvennyj Ermitazh, Sankt-Peterburg: 291-299.

Kul'kova M.A., Mazurkevich A.N., Dolukhanov P.M. 2001. Chronology and palaeoclimate of prehistoric sites in Western Dvina-Lovat area of North-western Russia. Geochronometria 20: 87-94.

Kul'kova M.A., Mazurkevich A.N., Dolbunova E.V., Lozovsky V.M. 2015a. The 8200 cal BP climate event and the spread of the Neolithic in Eastern Europe. Documenta Praehistorica 42: 77-92.

Kul'kova M.A., Mazurkevich A., Gerasimov D. 2015b. Stone Age archaeological sites and environmental changes during the Holocene in the NW region of Russia. In: J. Harff, G. Bailey, F. Lüth (eds) Geology and Archaeology: Submerged Landscapes of the Continental Shelf. Geological Society, London: 27-50.

Markov K.K. 1961. (ed.) Relyef i stratigrafiya chetvertichnykh otlozheniy Severo-Zapada Russkoy ravniny: K 6 kongressu INQUA v Varshave 1961. Izd-vo Akademii Nauk SSSR, Moskva.

Mazurkevich A.N. 1995. O rannem neolite LovatskoDvnskogo mezhdurechia. Peterburgskiy Arkheologicheskiy Vestnik 9: 77-84.

Mazurkevich A.N. 2003. Pervyye svidetelstva proyavleniya proizvodyashchego khozyaystva na Severo-Zapade Rossii. In: D.G. Savinov. V.N. Sedykh (eds) Pushkarevskiy sbornik II. Izd-vo S-Peterburgskogo un-ta, SanktPeterburg: 77-84.

Mazurkevich A., Dolbunova E. 2011. Underwater Investigations in Northwest Russia: lacustrine archaeology of Neolithic pile dwellings. W: J. Benjamin, C. Bonsall, C. Pickard, A. Fischer (red.) Submerged Prehistory. Oxbow Books, Oxford: 158-172.

Mazurkevich A., Dolbunova E. 2015. The oldest pottery in hunter-gatherer communities and models of Neolithisation of Eastern Europe. Documenta Praehistorica 42: 13-66.

Mazurkevich A.N., Miklyayev A.M. 1998. O rannem neolite mezhdurechia Lovati i Zapadnoy Dviny. Arkheologicheskiy Sbornik Gosudarstvennogo Ermitazha 33: 7-31.

Mazurkevich A., Dolukhanov P., Shukurov A., Zaitseva. G. 2009a. Mesolithic and Neolithic in the Western Dvina-Lovat Area. In: P.M. Dolukhanov, G.R. Sarson, A.M. Shukurov (eds) The East European Plain on the Eve of Agriculture, BAR International Series 164. Archaeopress, Oxford: 145-153.

Mazurkevich A., Korotkevich B.N., Dolukhanov P.M., Shukurov A.M., Arslanov Kh.A., Savel'eva L.A., Dzinoridze E.N., Kul'kova M.A., Zaitseva G.I. 2009b. Climate, subsistence and human movements in the Western Dvina - Lovat River Basins. Quaternary International 203: 52-66.

Mazurkevich A.N., Dolbunova E.V., Maigrot Y., Hookk D. 2011. Results of underwater excavations of Serteya II and research of piledwellings in Northwest Russia. Archaeologia Baltica 14: 47-64.

Mazurkevich A.N., Dolbunova E.V., Kul'kova M.A. 2012. Dynamics of landscape developing in early-middle Neolithics in Dnepr-Dvina region. International conference "Geomorphic Processes and Geoarchaeology: from Landscape Archaeology to Archaeotourism", Moscow-Smolensk. Russia, August 2012. Universum, Moscow-Smolensk: 20-24: 192-194.

Mazurkevich A., Dolbunova E., Kittel P. 2014. The phenomenon of pile-dwellings in NorthWestern Russia in the 4th-2nd mil. BC. Culture, Climate and Environment Interactions at Prehistoric Wetland Sites 11-14 June 2014. University of Bern, Switzerland, Bern: 25.

Mazurkevich A., Kittel P., Maigrot Y., Kul'kova M., Kazakov E., Dolbunova E., Sablin M., Lyashkevich E., Regert M., Mazuy A. 2016a. Landscape and natural resources use in the $3 \mathrm{rd}$ mill BC by pile-settlements' dwellers in NW Russia. 22th Annual Meeting of the EAA. 31st August-4th September 2016 Vilnius. The European Association of Archaeologists, Public Institution The Academy of Cultural Heritage, Vilnius: 644-645.

Mazurkevich A., Kittel P., Dolbunova E., Maigrot Y., Zaiceva G. 2016b. Cultural layer formation, production and dwelling areas on pile-settlements of Upper Dvina region. 22th Annual Meeting of the EAA. 31st August-4th September 2016 Vilnius. The European Association of Archaeologists, Public Institution The Academy of Cultural Heritage, Vilnius: 644655.

Mazurkevich A.N., Kittel P., Dolbunova E.V., Kazakov E.E., Faßbinder J., Sablin M.V., 
Maigrot Y. 2016c. Okruzhayushchaya sreda. landshaft Serteyskogo arkheologicheskogo mikroregiona i ego ispolzovaniye v III tys. do n.e. (po rezultatam novykh issledovaniy pamyatnika Serteya II). Mizhnarodnaja navukova-praktychnaja kanferencyja. Starazhytnasci III-I tys. da n.e. Belarusi i sumiezhnyh terytoryj: novyja pogljady i interpretacyi (da 80-goddzja dasliedavannja pasielishchaw Kryvinskaga Tarfianika). Pragrama i zbornik tezisaw dakladaw / International conference. Antiquities of III-I mill. b.c. of Belarus and adjacent territories: nev vievs and interpretations (dedicated to 80th anniversary of the research of Kryvina Peat-Bog settlements). Programme and abstract book / Mezhdunarodnaya nauchno-prakticheskaya konferentsiya. Drevnosti III-I tys. do n.e. Belarusi i sopredelnykh territoriy: novyye vzglyady i interpretatsii $(\mathrm{k}$ 80-letiyu issledovaniya poseleniy Krivinskogo Torfyanika). Programma i sbornik tezisov dokladov. 1-2 snezhnja 2016 goda. Instytut gistoryi NAN Belarusi, Minsk: 36-37.

Mazurkevich A., Dolbunova E., Kittel P., Kazalov E. 2017a. Lacustrine pile-dwellings of the 4-3rd mill BC: particularities of landscape, economy and culture (NW Russia). International Open Workshop. Socio-Environmental Dynamics over the Last 12,000 Years: The Creation of Landscapes V, Kiel, March 20-24, 2017. Graduate School at Kiel University, Kiel: 147.

Mazurkevich A., Dolbunova E., Kittel P., Fassbender J., Maigrot Y., Mroczkowska A., Płóciennik M., Sikora J., Słowiński M., Sablin M., Shirobokov I. 2017b. Multi-disciplinary research on the Neolithic pile-dwelling Serteya II site (Western Russia) and the landscape reconstruction. In: A. Marciniak-Kajzer, A. Andrzejewski, A. Golański, S. Rzepecki (eds) Nie tylko krzemienie. Not only flints. Instytut Archeologii Uniwersytetu Łódzkiego, Łódzka Fundacja Badań Naukowych, Stowarzyszenie Naukowe Archeologów Polskich Oddział w Łodzi, Łódź: 103-128.

Miklyayev A.M., Mazurkevich A.N., Doluhanov P.M., Zajceva G.I. 1987. O rannem neolite severa Smolenskoy oblasti i yuga pskovskoy oblasti. In: V.P. Shilov (ed.) Zadachi sovetskoy arkheologii $v$ svete resheniy XXVII syezda KPSS. Nauka, Moskva: 169-170.

Piech W., Kittel P., Mazurkevich A., Pavlovskaia E., Kazakov E., Teltevskaya Y., Błaszczyk K., Kotrys B. 2018. Cechy sedymentologiczne i warunki osadów stożka akumulacyjnego w dolinie rzeki Sertejki (zachodnia Rosja). Acta Geographica Lodziensia 107; 215-238.

Polkovnikova M.E. 2014. Kamennyy inventar' svaynogoposeleniya Serteya II. Material mezhdunarodnoy konferentsii, posvyashchennoy poluvekovomu issledova svaynykh poseleniy na Severo-Zapade Rossii „Arkheologiya ozernykh poseleniy 4-2-go tys. do n.e.: khronologiya kul'tur i prirodno-klimaticheskiye ritmy". Sankt-Peterburg, 13-15 Noyabrya 2014 G. Gosudarstvennyy Ermitazh, SanktPeterburg: 271-274.

Sablin M.V., Siromyatnikova E.V. 2009. Animal remains from Neolithic sites in northwestern Russia. In: P.M. Dolukhanov, G.R. Sarson, A.M. Shukurov (eds) The East European Plain on the Eve of Agriculture. BAR International Series 1964. Oxford: Archaeopress: $153-158$

Tarasov P.E., Savelieva L.A., Long T., Leipe C. 2018 (in press). Postglacial vegetation and climate history and traces of early human impact and agriculture in the present-day cool mixed forest zone of European Russia. Quaternary International

https://doi.org/10.1016/j.quaint.2018.02.029

Velichko A.A., Faustova M.A., Pisareva V.V., Gribchenko Yu.N., Sudakova N.G., Lavrentiev N.V. 2011. Glaciations of the East European Plain: Distribution and Chronology. Developments in Quaternary Science 15: 337-359.

Zajceva G.I., Vasil'ev S.S., Dergachev V.A., Mazurkevich A.N., Semencov A.A. 2003. Novyye issledovaniya pamyatnikov basseyna $\mathrm{Za}$ padnoy Dviny i Lovati: raspredeleniye radiouglerodnykh dat. korrelyatsiya s izmeneniyem prirodnykh protsessov. primeneniye matematicheskoy statistiki. Drevnosti Podvinia. istoricheskiy aspekt: po materialam kruglogo stola. posvyashchennogo pamyati A.M. Miklyayeva. 6-8 oktyabrya 1999 g. Gosudarstvennyj Ermitazh, Sankt-Peterburg: 140-154.

\section{Streszczenie}

Dolina współczesnej rzeki Sertejki, dopływu Dźwiny, wykorzystuje rynnę subglacjalną ukształtowaną w trakcie zlodowacenia wisły (wałdajskiego). W późnym vistulianie i w holocenie w rynnie funkcjonował przez długi czas system paleojezior, co najmniej dwu generacji. Rzeka Sertejka stopniowo zdrenowała zbiorniki jeziorne w wyniku erozji wstecznej. Proces ten przypadał zapewne głównie na fazy transgresji paleojezior. System fluwialny zastąpił ostatecznie system limniczny w późnym holocenie. Wahania poziomu wody miały silny wpływ na warunki rozwoju lokalnego osadnictwa. Gęstość zaludnienia zależały od regionalnych zmian klimatycznych i lokalnego krajobrazu. Szczególnie bogate i intersujące są relikty osadnictwa neolitycznego odkrywane w dnie współczesnej doliny Sertejki. W obrębie jednego z największych zbiorników paleojeziornych funkcjonowa- 
ła neolityczna osada palifitowa Serteya II. Warunki środowiskowe stanowiska wydają się być szczególnie korzystne dla społeczności neolitycznych opartych przede wszystkim o gospodarkę przyswajalną, w tym głównie rybołówstwo. W trakcie regresji wód paleojeziora środowisko obszaru cechowało się wysoką geoi bioróżnorodność, a w krajobrazie dominowały małe jeziora, niewielkie cieki i żyzne gleby hydrogeniczne. Dlatego ważnym celem badań multidyscyplinarnych jest rekonstrukcja zmian paleohydrologicznych i paleoklimatycznych obszaru oraz ich wpływu na lokalne osadnictwo.

Prace archeologiczne na stanowisku Serteja II pozwoliły na wydzielenie zróżnicowanych pod względem funkcjonalnym stref w obrębie obszaru użytkowanego osadniczo. Wyróżniono strefę podmokłą stanowiącą centralną część osady palafitowej, której relikty odkrywane są $\mathrm{w}$ obrębie osadów jeziornych. W strefie brzegowej paleojeziora odkryto relikty zabudowy związanej z zajęciami gospodarczymi, w tym oprawianiem tusz zwierząt. Odkryto tu również części szkieletów trzech osobników - dwu młodych kobiet i mężczyzny. Osada funkcjonowała w 3 tysiącleciu p.n.e. Znaczące jest to, że główna faza rozwoju osady palafitowej przerwana została $\mathrm{w}$ trakcie chłodnej oscylacji klimatycznej 4,2 ky. BP. Kontekst geoarcheologiczny jej istnienia, sugeruje występowanie krótkotrwałych regresji paleojeziora właśnie przed $4200 \mathrm{BP}$, co skutkowało zakładaniem zabudowy typowej dla obszarów okresowo zalewanych. Osada palafitowa przetrwała długi okres, zanim została ponownie zatopiona.

Osadnictwo późnoneolityczne funkcjonowało na przełomie okresu atlantyckiego i subborealnego, kiedy to doszło do przebudowy zbiorowisk roślinnych i zmiany warunków klimatycznych w Europie. Nowa, palafitowa architektura była adaptacją do zmiennych warunków hydroklimatycznych w subboreale. Zróżnicowana geomorfologia doliny (od systemów jeziornych do fluwialnych i mokradłowych) silnie wpływała na warunki życia społeczności neolitycznej w rejonie Serteji. 